Article

\title{
A Fuzzy-AHP Methodology for Planning the Risk Management of Natural Hazards in Surface Mining Projects
}

\author{
Philip-Mark Spanidis ${ }^{1}$, Christos Roumpos ${ }^{2, *(D)}$ and Francis Pavloudakis ${ }^{2}$ \\ 1 ASPROFOS Engineering, Division of Project Management, 17675 Athens, Greece; pspani@asprofos.gr \\ 2 Public Power Corporation of Greece, Mining Engineering Department, 10432 Athens, Greece; \\ f.pavloudakis@dei.com.gr \\ * Correspondence: c.roumpos@dei.com.gr; Tel.: +30-210-5109500
}

Citation: Spanidis, P.-M.; Roumpos, C.; Pavloudakis, F. A Fuzzy-AHP Methodology for Planning the Risk Management of Natural Hazards in Surface Mining Projects. Sustainability 2021, 13, 2369. https://doi.org/ $10.3390 /$ su13042369

Academic Editor:

Kwame Awuah-Offei

Received: 14 January 2021

Accepted: 17 February 2021

Published: 22 February 2021

Publisher's Note: MDPI stays neutral with regard to jurisdictional claims in published maps and institutional affiliations.

Copyright: (c) 2021 by the authors. Licensee MDPI, Basel, Switzerland. This article is an open access article distributed under the terms and conditions of the Creative Commons Attribution (CC BY) license (https:// creativecommons.org/licenses/by/ $4.0 /)$.

\begin{abstract}
Surface mining projects are vulnerable to natural hazards (earthquakes, floods, soil instabilities, and epidemic crises) which constitute the primary source of risks which affect the mining operations. In the framework of sustainable planning and development of such projects, the investigation of risk impacts is essential for taking the appropriate preventive measures before disastrous events appear in a mine. This paper proposes a methodology for the risk assessment of natural hazards in surface mining projects using the triangular Fuzzy Analytical Hierarchy Process (FAHP) for the determination of the probability of risk occurrence, combined with the Expected Value (EV) function, the Monte Carlo simulation, and the Program Evaluation Review Technique PERT method for making predictions of cost and time overruns. A case study of a hazardous event with impacts in the operations of a surface mine demonstrates the methodology as a flexible and low-cost tool for mining executives. This tool is useful in the planning stage of pre-disaster management projects in the mineral industry, considering mine sustainability views. The research work also investigates critical technical and economic aspects.
\end{abstract}

Keywords: fuzzy analytical hierarchy process; hazards; surface mines; risk management

\section{Introduction}

The activities of surface mining projects usually extend over large geographical regions and last for many decades. The consequences of mining operations are often related to the significant changes in the mine geomorphology as well as to the significant impacts on soil formations, ecological features, and local microclimatic conditions [1-3]. Thus, the initial physical and geo-environmental form of a surface mine is subject to radical alterations making mines particularly vulnerable when natural hazards of high intensity, such as earthquakes, fires, floods, or landslides, make their appearance.

Natural hazards are phenomena and processes that occur in the Earth's systems, which appear instantaneously and may cause disasters in various intension levels with harmful effects to humans, the environment, and property. According to the UN International Strategy for Disaster Risk reduction [4] (also [5-7]):

- A hazard is a potentially damaging physical event, phenomenon, or human activity that may cause the loss of life or injury, property damage, social and economic disruption, or environmental degradation;

- A disaster is a severe disruption of the functioning of a community or a society causing widespread human, material, economic or environmental losses which exceed the ability of the affected community or society to cope using its resources;

- $\quad$ Risk is the probability of occurrence of an uncertain event multiplied by the resulting cost or benefit, if this event takes place.

In natural hazard investigations, risk represents a more complicated entity involving the nature and intensity of the hazardous events, the conditions of vulnerability, and the measures taken for reducing the potential of negative consequences of the risk. 
Considering the above definitions, it is evident that hazards and disasters are interactive and interrelated entities. Therefore, the analysis of their potential impacts on a specific societal, environmental, or industrial system requires empirical evidence and multidisciplinary scientific substantiation. There are several ways to classify natural hazards, but the most representative categories of them referred to in the literature are the atmospheric, geophysical, hydrological, fires of non-human intervention, and biological hazards as well [8-10].

Surface mining projects are long-term operations with considerable disturbance of the physical and man-made environment. They are also characterized by extensive horizontal development and the use of high capacity and heavy-duty mechanical means and equipment [11-14]. These impacts dramatically increase the initial-physical geoenvironmental form of mines and constitute the main reason for the insertion of crucial risks into mining operations. The extended excavations, earthmoving, and backfilling works affect topography and landforms and disturb ecosystems in many different ways that may trigger hazardous situations insofar as natural phenomena of high intension known as "climate extremes." These mainly include enormous floods, earthquakes, and fires, as well as land movements. Another important issue is the impacts of natural hazards to mine sustainability meant as negative effect(s) to optimization of human resources and technical means, economy in fuels/energy consumption, integrity of affected soil and landforms, provisions of post-mining environmental upgrading, and the potential beneficial returns to the affected by the mining operations societies and land use settlements.

Thus, mining personnel, equipment, facilities, and mine sustainability are exposed to risk in multiple ways, with potential effects on life, livelihood, and safety of human societies living in the greater area of the mine. The mining operations are human-made invasive processes of large scale. The natural hazards, mainly related to landslides, soil subsidence, slope instabilities and local flooding, and disasters is an issue of growing concern as the climate extremes present an increasing trend worldwide $[7,9,15]$. Surface mines are exposing disastrous effects due to various reasons. Some of the most acute effects are $[1-3,13,16,17]$ :

- Drastic changes of natural terrains relief, landscape, and topography,

- Reduction of soil cohesion resulting from intensive excavations and pits opening,

- Soil liquefaction related to the use of explosives and vibrations generated by heavyduty excavation equipment and means for transportation of ore (shovels, belt conveyors, wagons, etc.),

- Soil disturbance due to the opening of access roads and site grading/levelling works,

- Modifications of hydrology, according to mine development and closure,

- Lowering of soil consistency caused by the removal of topsoil and planation systems,

- Effects on slope stability [1],

- Disposal of excavated ore piles, waste material, surplus soil or aggregates,

- Intensive and extended utilization of technical means/machinery for increasing ore production,

- Reduction of the mining system environmental sustainability.

All the above interventions constitute the surface mines particularly vulnerable to natural hazards.

It worth noticing that underground mines are also high-risk operations in relation to natural hazards. There are several classifications of causal factors that trigger hazards in underground mines [18-21]. Environmental factors can be further divided into geomechanical, geochemical, and biological. Some of the most common accidents in underground mines are classified in this group, such as water inundation, escapeway egress blockage, natural gas ingress, spontaneous combustion causing fire or explosion, and un-planned detonation of blast. Other categories of causal factors are psychosocial (i.e., related to physical or mental stress), mechanical and electrical (e.g., workshop fire), procedural, and managerial. In all cases, the fact that in underground mining most of the activities are performed in confined spaces increases the probability of workers' exposure to elements 
that cause death, illnesses, or affect their health in numerous ways. On the other hand, the smaller scale of works compared to surface mining as well as the smaller surface area occupied by excavations and dumps reduce the probability and severity of extreme incidents that threaten the environment.

In this view, the examination of the risks associated/caused by the natural hazards requires further elaboration for the necessary proactive and reactive measures to be appropriately planned, designed, and implemented. The development of an effective pre-disaster plan is particularly crucial for the operation of every surface mine, since the huge natural, human, environmental, and financial resources required for mitigating the impacts of a large-scale natural hazard can jeopardize the sustainable planning of the entire project.

In the mining industry, the investigation of natural hazards is a topic on which literature presents interesting references from researchers and academics. Donoghue [22] examined the natural occurrence of hazards and their consequences, such as rockfalls, fires, explosions, flooding, etc. as leading causes of traumatic injuries or fatalities for personnel working in the mining industry. Wang et al. [23] assesses the risk of the floor water invasion in coal mines as a factor of generating hazardous conditions in regular mining operations and advises a fuzzy evaluation system to investigate the relevant risks. Pavloudakis et al. [24] analyse the effects of the environmental damages caused by the intensive operation of a surface lignite mine and review the relevant regulatory aspects and public involvements, with emphasis on the provisions of the Aarhus Convention. Azharib and Ozbaya [25] investigated 177 different cases of hazards caused by seismic activity in open-pit mines showing the importance of the excess pore pressure as a significant risk factor for earthquake-triggered failures in highly excavated mines with steep slope formations. Park et al. [26] researched the role of coal spoil and tailing wastes that may cause environmental problems and associated risks with potential failures of tailing dam constructions, as well as the associated geochemical effects such as acid mine drainage and presence of saline water and heavy metals.

The work of Kasap and Subasi [27] deals with the prevention of industrial accidents reported in the period 2005-2010, such as deaths, physical disabilities, and financial losses in open-pit coal mines, in case of hazards occurrence caused by landslides, with a risk analysis developed using the Analytic Hierarchy Process (AHP) technique. Ferrari et al. [28] presented a new procedure for execution of a qualitative assessment for the rockfall hazards designed for the Australian open-pit coal mining systems to identify the most hazardous high-wall locations and improve the locating of personnel, machinery, and infrastructures over the working areas of a lignite mine. McQuillan et al. [29], using data from 119 intact case studies from coal surface mines in Australia, developed a methodology for the investigation of risks and associated hazards in failures observed at areas with large scale and steep slope excavations. Spanidis et al. [12] analyse and identify the principal risk factors and sub-factors in mining processes sourced from natural or technological processes and their consequences to property, production, and people along with a risk management framework for the analysis and upfront examination of hazardous scenarios making focus in the phase of closing and restoration of a surface lignite mine. Lemly [30] provides an analysis of the environmental hazards with impacts on the quality of federally and provincially protected aquatic habitats at an area located in southwest Alberta, Canada, where the Grassy Mountain Coal project has planned for implementation. Dos-Santos et al. [31] carried out a hazard assessment using data of harmful phenomena caused by rainfalls and enhanced by blasting activities and steep slope shapes generated by intensive excavation activities in 88 open-pit mines. Pavloudakis et al. [14] also provide analysis and classification of technological and natural hazards with effect to the planning and development of a surface lignite mine and elaborate on a series of factors determining the impacts of the identified hazards to people, human activity, and ecosystems located in the broader area of the mining site.

The above review shows that the hazardous phenomena, induced by natural factors in established mining systems, is a particularly challenging issue which requires further 
scientific research. The perspective of assessing the natural hazards risks to develop predisaster preventive management plans and to recommend tools and emergency practices for understanding and organization of proactive measures, and, at a later stage, to react, mitigate, and recover the post-hazard disastrous situations, seems to be challenging for mining management. The pre-disaster management projects are also related to the quantification of the probabilities of risk occurrence, so that the assessment of any possible disastrous scenario, suggesting the appropriate proactive and reactive measures, must be well documented, reasonable, and cost-effective.

Mining practice shows that there is not a formal manner of addressing natural hazards in surface mines because of the uncertainties regarding the type, extent, and consequences of any hazard. Besides, the risk management philosophies differ significantly from one surface mine to another. Thus, the investigation of mining risk management, considering natural hazards, is critical in the formulation of functional and technical context of a management plan developed against the consequences of natural hazards.

The innovative aspects contributed by the present study to the research in the field of natural hazard effects in the mining industry is the analysis of the bilateral relationship between mining systems and environment based on sustainability principles. Mining operations are complex engineering systems, where the risk sources may be human, mechanical, and environmental. The impacts of mining systems on the environment and its immediate surroundings, as well as the impacts of the environment on mining systems, defined the frame where the sustainable development of mine operation has been investigated.

Section 2 addresses risk management problems and research questions. Section 3 presents the surface mining project setting of the case study and states the proposed methodology. Section 4 demonstrates the results of the applied methodology. Section 5 discusses the FAHP results and the managerial and techno-economical aspects of the methodology Finally, Section 6 provides conclusions and proposals for further research.

\section{Risk Management: Problems and Research Questions}

There are various definitions of risk depending on the aims as well as the related research field. Customarily, risk refers to the probability of occurrence of an uncertain event (e.g., condition, damage, hazard, injury, fatality, liability, or loss) multiplied by the resulting cost or benefit, if this event takes place [32]. In natural hazard investigations, risk represents a more complicated entity involving the nature and intensity of the hazardous phenomena and the preventive measures taken for reducing the negative consequences of risks $[4,7,33]$. The disasters of potential natural hazards in surface mines are subject to indepth multidisciplinary research and exhaustive analysis of potential risks and risk impacts with effect to mining assets and personnel, along with evaluations of financial losses because of damages recovery and restoration and non-productive time elapses as well. All previous facts shape the basis for the deployment of an effective disaster management plan comprising of pre-disaster organizational functions and settings, prevention measures, emergency plans, and post-disaster relief activities and recovery [34] of the damaged assets known as "elements at risk" $[4,7,35]$. The investigation and identification of natural hazards risks is multidisciplinary research that takes into consideration various parameters and technical limitations. In particular:

(a) The validity of risk analysis depends on the availability and reliability of actual data (frequency, intension, duration, location, meteorological parameters, etc.) collected through various methods and at different levels of accuracy. Often, these data are insufficient, heterogeneous, or less appropriate for use [36-38].

(b) Each mine has its own meteorological, topographical, geological, environmental, and hydrological features. For example, one mine at a long distance from the sea is less prone to extreme sea water movements (e.g., tsunamis), while another mine might operate at a location prone to seismic activity. Therefore, the criticality and impact of identified hazards differ significantly from one mine to another [12-14]. 
(c) The vulnerability of a particular mine depends on the efficiency of proactive measures taken against potential disasters. It relates to the efficiency of safety measures [39] for quick evacuation of personnel, transfer of valuable machinery at safer locations, or saving of expensive field equipment, in cases of emergency. Mining industry experience shows that not all mines have the same level of readiness for withstanding natural hazards.

(d) The phase of the life cycle that a surface mine operates is another aspect related to the magnitude of risks. For instance, due to the extended geoenvironmental changes, a mine entering the closing phase seems to be likely more vulnerable and highly exposed to natural hazards than another mine running the exploitation, or early development phase $[13,14]$.

Thus, mining executives, in order to plan, manage, and execute a practical pre-disaster project must take necessary actions to assess the hazardous effects of risks and propose appropriate prevention, mitigation, and recovery measures responding to critical research questions such as:

(1) How should the natural hazard risks be assessed based on scientific reasoning and acquisition of empirical evidence, judgement, and knowledge from mining experts?

(2) Is it possible to organize and execute the prevention of mine disasters in terms of a project embodying the theoretical background and practices of project and risk management?

(3) Are there any methods, tools, or techniques appropriate for a mathematically consistent determination of the probability that a natural hazard event will occur with effects to mining operations and for a proactive risk impact analysis as well?

(4) Is it possible to define the elements at risk and to use them in disastrous scenarios analyses?

(5) Is there any substantial methodology for quantitative evaluations of time and cost overruns required for a useful pre-disaster management project and the implementation of post-disaster recovery and restoration measures/means/actions in a mine?

The above questions dictate that pre-disaster management in mining must be as objective as possible and reasonable as well. Thus, it must be organized and planned on the ground of risk-based probabilistic analysis and impacts assessment and according to the principles of project and risk management. The literature demonstrates that the advantages/benefits from the introduction of risk management methods in project contexts are particularly interesting [40-42] insofar as Geographic Information Systems GIS and remote sensing technologies may contribute to the relevant research $[7,43]$. As the mining systems are long-term projects of high complexity, the risk management practices must ensure not merely ore production, but also the management of potential disasters caused by natural hazards. Literature shows that natural hazards become more frequent and intensive over time $[9,15,44,45]$, and this fact leads the scientific research to assess how hazards, disasters, and risks in mining environments are associated entities of high interaction [46]. The investigation of natural hazards shows that risk inducing factors like fires, explosions, soil and water pollution, ecological effects, toxicity, etc. [47-50] constitute the process of risk investigation as quite complex and multidisciplinary. Therefore, a more detailed approach in investigating the risks thoroughly, and the way and extent they affect the mining operations and establishments, as individual or synergistic phenomena, needs further research.

\section{Materials and Methods}

\subsection{Surface Mining Project Setting}

The proposed methodology refers to a coal surface mine which is equipped with bucket wheel excavators, conveyors, and spreaders, while a multitude of other noncontinuous mining machinery and infrastructures are in place too (Figure 1). The mine feeds with lignite a $480 \mathrm{MW}$ power plant located about $2.5 \mathrm{~km} \mathrm{NE}$ from the mine. The mine is continuously operating for ten years while the mine's remaining life is 20 years. The area 
of the mining field covers approximately $10 \mathrm{~km}^{2}$. The mine surface is mainly hilly with altitudes ranging between $+350 \mathrm{~m}$ and $+400 \mathrm{~m}$ above sea level. The lignite deposit is of multiple-layered form, and the lignite seams are horizontally placed.

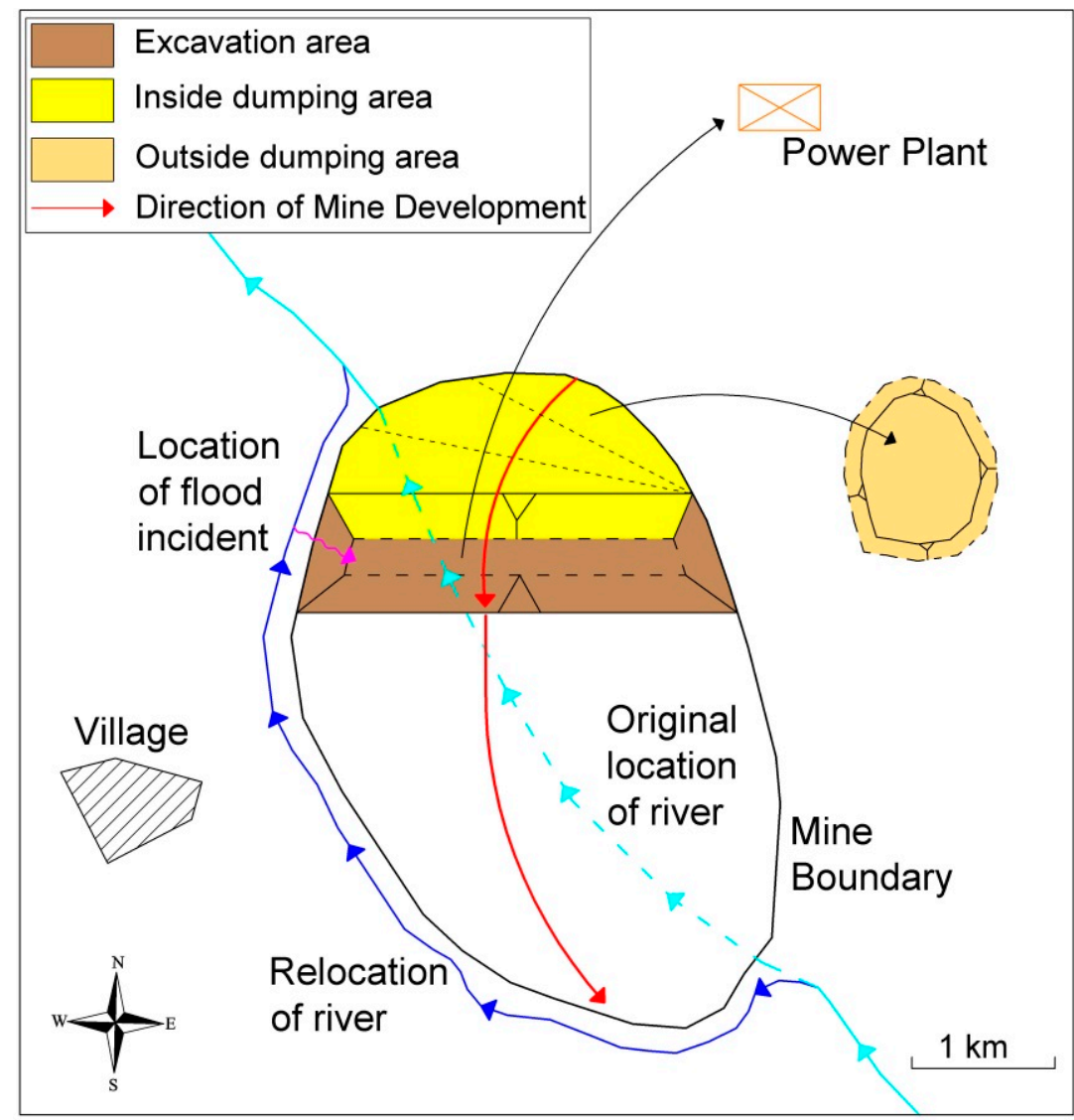

Figure 1. General overview of the surface mining area (designed by the authors).

The outside waste dumping area is located about $1 \mathrm{~km} \mathrm{E}$ from the mine and has been completed. Therefore, the waste material from the exploitation activities is transported to the inside dumping area. At a distance of about $1 \mathrm{~km} \mathrm{~W}$, there is a village with approximately 100 inhabitants. A river with SE/NW direction was initially located in the mining mine. The river flow has been partially modified for exploitation needs. Following the mine closure, a lake has been planned to fill the final pit voids. Before the beginning of mining activity, the land use was mainly agricultural and forestry.

\subsection{Proposed Methodology}

\subsubsection{General Concept}

The impacts of natural hazards to the elements at risk (e.g., personnel, infrastructures, and machinery) concentrate the interest of mining executives, managers, and decisionmakers. The methodology suggested hereunder deals with a probabilistic analysis of natural hazards that might affect a surface mine and how this analysis could be useful in pre-disaster project management, in terms of cost and time overruns evaluation. The general concept of the methodology consists of the following:

(a) Understanding the origin, content, magnitude, and potential impacts of natural hazards.

(b) Determination of the probability, in the form of weight factors and sub-factors, that natural hazards risk will occur, by applying the Fuzzy Analytical Hierarchy Process (FAHP) method. The mathematical calculations of FAHP embody data collected 
from empirical evidence and aggregation of knowledge from experts in the mining industry.

(c) Structuring a risk and impact severity matrix enabling the multidisciplinary evaluation and classification of impacts to the elements at risk of a typical surface mining system.

(d) Development of a hazardous scenario for a surface mine and elaboration of a technoeconomic analysis of post-disaster cost and time overruns, using the Expected Value (EV) function for prediction of the restoration cost using also the Monte Carlo simulation and Program Evaluation Review Technique PERT technique for the prediction of critical cost and time parameters.

\subsubsection{AHP and Fuzzy AHP}

The AHP advised by Saaty [51] is a groupware multi-criteria decision-making method of high effectiveness, enabling the integration of experts' opinions by decomposing complex problems from a higher level of hierarchy to lower one. The AHP is a flexible quantitative method appropriate for the selection of the most advantageous solution from a set of alternatives based on their relative performance considering one or more criteria of interest [51-53]. The hierarchy is based on pair-wise comparisons of individual judgements for the evaluation criteria and, in sequence, on pair-wise comparisons of the alternative solutions over each one of the selection criteria. Based on that, the performance of each alternative is outlined. The data required for the AHP calculations are carryed out through interviews with experts or using properly structured questionnaires delivered to experts.

Literature shows that AHP has been extensively adopted by academia and industry in resolving decision-making problems of high complexity or in the determination of the weights of specific criteria which are combinable with other operational or probabilistic techniques, like the AHP/SWOT (Strengths, Weaknesses, Opportunities and Threats) hybrid method [54] and the AHP combination with decision trees analysis [42]. The fields of AHP development are much extended: financial management, transportation, medical and pharmaceutical science [55,56], oil refineries [42], petroleum pipelines [9,57], surface mines restoration $[12,58]$, construction management [59], and others.

However, AHP presents various practical problems. First, the overall performance of the method decreases as the number of criteria and alternatives increase. Second, the method does not allow rationalization of the vagueness regarding personal judgements of evaluators (experts). Especially in cases of uncertain and complicated nature of a problem, the transformation of personal judgement and knowledge of experts into numerical entities becomes difficult. Third, experts feel more confident when using linguistic expressions to interpret their insight and perception of real-world conditions explicitly instead of making numerical identifications. For these reasons, researches prefer the use of fuzzy logic theory to enrich the mathematical concept of simple AHP [60,61].

For experts, the identification of criteria and the evaluation of alternatives seem more comfortable when they must elaborate linguistic terms, like "equally important," "low," "moderate," "high," etc. Thus, the Fuzzy AHP (FAHP) has been steadily developed as an efficient tool in resolving decision-making problems. Nevertheless, the philosophy of fuzzy sets has been extended to other Multi-Criteria Decision Making Methods MCDM methods [62] as, for instance, the fuzzy TOPSIS (Technique for Order of Preference by Similarity to Ideal Solution) [63] and fuzzy PROMETHEE (Preference Ranking Organization METHod for Enrichment of Evaluations) [64] methods. The linguistic terms used in FAHP for the pair-wise comparisons can be quantified by adopting a 1-9 scale of Saaty and the corresponding fuzzy numbers conversion scale of relative importance as shown below in Table $1[65,66]$. 
Table 1. Fuzzy scale of the relative importance (Kannan et al. [65]).

\begin{tabular}{ccc}
\hline $\begin{array}{c}\text { Saaty } \\
\text { Scale }\end{array}$ & $\begin{array}{c}\text { Definition of } \\
\text { Linguistic Terms }\end{array}$ & Triangular Fuzzy Numbers Scale \\
\hline 1 & Equal (EQ) & $(1,1,1)$ \\
3 & Moderate (MD) & $(2,3,4)$ \\
5 & Strong (ST) & $(4,5,6)$ \\
7 & Very Strong (VS) & $(6,7,8)$ \\
9 & Extremely Strong (ES) & $(9,9,9)$ \\
2 & & $(1,2,3)$ \\
4 & Intermediate Values & $(3,4,5)$ \\
6 & & $(5,6,7)$ \\
8 & & $(7,8,9)$ \\
\hline
\end{tabular}

\subsubsection{Mathematical Definitions and Operations}

A set of fuzzy numbers $\tilde{A}$ in $X \subseteq R$, where $R$ is the set of real numbers, is defined as a set of ordered pairs $\tilde{\mathrm{A}}=\{\mathrm{x}, \mu \tilde{\mathrm{A}}(\mathrm{x})\}, \mathrm{x} \in \mathrm{X}$ and $\mu \tilde{\mathrm{A}}(\mathrm{x}): \mathrm{X} \rightarrow[0,1]$. The function $\mu \tilde{\mathrm{A}}(\mathrm{x})$ is the membership function of $\tilde{\mathrm{A}}$ that assigns to each object $\mathrm{x}$ a grade of membership varying from 0 to $1[67,68]$. A fuzzy number is a particular case of a normalised fuzzy set $[68,69]$. There are various types of fuzzy numbers but the most usual and practical are the triangular and the trapezoid ones. Trapezoid fuzzy numbers deal with more general situations of vagueness in the concepts of decision-making analysis [68]. For practical reasons, the authors adopted Buckley's triangular fuzzy numbers (TFN).

In the two dimensional Cartesian system, the membership function $\mu \tilde{\mathrm{A}}(\mathrm{x}): \mathrm{X} \rightarrow[0,1]$ of a TFN is represented by the following Equation (1), $\{\mathrm{L}, \mathrm{M}, \mathrm{U}\} \in \mathrm{R}$ and $\mathrm{L}<\mathrm{M}<\mathrm{U}$ :

$$
\mu \tilde{\mathrm{A}}(\mathrm{x})=\left\{\begin{array}{l}
\frac{(\mathrm{x}-\mathrm{L})}{(\mathrm{M}-\mathrm{L})} \text { for } \mathrm{L}<\mathrm{x}<\mathrm{M} \\
\frac{(\mathrm{U}-\mathrm{x})}{(\mathrm{U}-\mathrm{M})} \text { for } \mathrm{M}<\mathrm{x}<\mathrm{U} \\
0 \text { for } \mathrm{x} \notin[\mathrm{L}, \mathrm{M}] \wedge \mathrm{x} \notin[\mathrm{M}, \mathrm{U}]
\end{array}\right.
$$

where the parameter $\mathrm{L}$ represents the lower bound, $\mathrm{U}$ the upper bound, and $\mathrm{M}$ the modal value of the membership function $\mu \tilde{\mathrm{A}}(\mathrm{x})$. A TFN is represented by the three elements set $\tilde{\mathrm{A}}=(\mathrm{L}, \mathrm{M}, \mathrm{U})$. Specific definitions and mathematical explanations are defining the TFNs operations used in the fuzzy analysis (Equations (2-9)), which are as follows [66,70]:

(a) Definitions R: the set of real numbers; $\mathrm{N}$ : the set of natural numbers L1 $>0$; L2 $>0$; $\mathrm{M} 1>0$; $\mathrm{M} 2>0 ; \mathrm{U} 1>0 ; \mathrm{U} 2>0 ; \mathrm{p} \in \mathrm{R} ; \mathrm{p}>0 ; \mathrm{q} \in \mathrm{R} ; \mathrm{q} \neq 0 ;\{\mathrm{Lm}, \mathrm{Mm}, \mathrm{Um}\} \in \mathrm{R}$; $\mathrm{L}<\mathrm{M}<\mathrm{U} ; \mathrm{m} \in \mathrm{N}$

(b) Addition of two TFNs $\oplus$ :

$$
\tilde{\mathrm{A}}_{1}=\left(\mathrm{L}_{1}, \mathrm{M}_{1}, \mathrm{U}_{1}\right) ; \tilde{\mathrm{A}}_{2}=\left(\mathrm{L}_{2}, \mathrm{M}_{2}, \mathrm{U}_{2}\right) ; \tilde{\mathrm{A}}_{1} \oplus \tilde{\mathrm{A}}_{2}=\left(\mathrm{L}_{1}+\mathrm{L}_{2}, \mathrm{M}_{1}+\mathrm{M}_{2}, \mathrm{U}_{1}+\mathrm{U}_{2}\right)
$$

(c) Multiplication of two TFNs $\otimes$ :

$$
\tilde{\mathrm{A}}_{1}=\left(\mathrm{L}_{1}, \mathrm{M}_{1}, \mathrm{U}_{1}\right) ; \tilde{\mathrm{A}}_{2}=\left(\mathrm{L}_{2}, \mathrm{M}_{2}, \mathrm{U}_{2}\right) ; \tilde{\mathrm{A}}_{1} \otimes \tilde{\mathrm{A}}_{2}=\left(\mathrm{L}_{1} \cdot \mathrm{L}_{2}, \mathrm{M}_{1} \cdot \mathrm{M}_{2}, \mathrm{U}_{1} \cdot \mathrm{U}_{2}\right)
$$

(d) Subtraction of two TFNs $\ominus$ :

$$
\tilde{\mathrm{A}}_{1}=\left(\mathrm{L}_{1}, \mathrm{M}_{1}, \mathrm{U}_{1}\right) ; \tilde{\mathrm{A}}_{2}=\left(\mathrm{L}_{2}, \mathrm{M}_{2}, \mathrm{U}_{2}\right) ; \tilde{\mathrm{A}}_{1} \ominus \tilde{\mathrm{A}}_{2}=\left(\mathrm{L}_{1}-\mathrm{L}_{2}, \mathrm{M}_{1}-\mathrm{M}_{2}, \mathrm{U}_{1}-\mathrm{U}_{2}\right)
$$

Division of two TFNs $\oslash$ :

$$
\begin{gathered}
\tilde{\mathrm{A}}_{1}=\left(\mathrm{L}_{1}, \mathrm{M}_{1}, \mathrm{U}_{1}\right) ; \tilde{\mathrm{A}}_{2}=\left(\mathrm{L}_{2}, \mathrm{M}_{2}, \mathrm{U}_{2}\right) ; \tilde{\mathrm{A}}_{1} \oslash \tilde{\mathrm{A}}_{2}=\left(\frac{\mathrm{L}_{1}}{\mathrm{~L}_{2}}, \frac{\mathrm{M}_{1}}{\mathrm{M}_{2}}, \frac{\mathrm{U}_{1}}{\mathrm{U}_{2}}\right) \\
\text { If } \tilde{\mathrm{A}}=\left(\mathrm{L}_{1}, \mathrm{M}_{1}, \mathrm{U}_{1}\right) \Rightarrow(\tilde{\mathrm{A}})^{-1}=\left(\frac{1}{\mathrm{U}_{1}}, \frac{1}{\mathrm{M}_{1}}, \frac{1}{\mathrm{~L}_{1}}\right)
\end{gathered}
$$


(e) Multiplication of a TFN by a constant $\mathrm{p}$ :

$$
\tilde{\mathrm{A}}=\left(\mathrm{L}_{1}, \mathrm{M}_{1}, \mathrm{U}_{1}\right) ; \tilde{\mathrm{A}} \otimes \mathrm{p}=\left(\mathrm{p} \cdot \mathrm{L}_{1}, \mathrm{p} \cdot \mathrm{M}_{1}, \mathrm{p} \cdot \mathrm{U}_{1}\right)
$$

(f) Division of a TFN by a constant q:

$$
\tilde{\mathrm{A}}=\left(\mathrm{L}_{1}, \mathrm{M}_{1}, \mathrm{U}_{1}\right) ; \tilde{\mathrm{A}} \oslash \mathrm{q}=\left(\frac{\mathrm{L}_{1}}{\mathrm{q}}, \frac{\mathrm{M}_{1}}{\mathrm{q}}, \frac{\mathrm{U}_{1}}{\mathrm{q}}\right)
$$

A TFN can be defined by its corresponding left and right representation of each degree of membership (Figure 2) as in the following Equation (9) [66,71]:

$$
\tilde{\mathrm{A}}=\mathrm{A}^{\mathrm{L}(\mathrm{y})}, \mathrm{A}^{\mathrm{R}(\mathrm{y})}=(\mathrm{L}+(\mathrm{M}-\mathrm{L}) \mathrm{y}, \mathrm{U}+(\mathrm{M}-\mathrm{U}) \mathrm{y}) ; \mathrm{y} \in[0,1]
$$

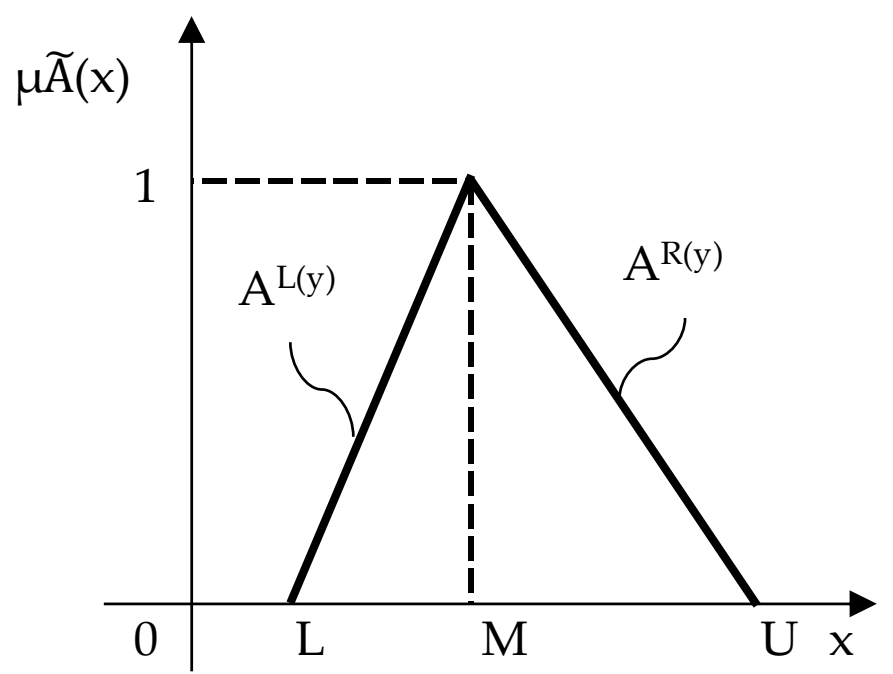

Figure 2. Triangular fuzzy numbers (TFNs) representation (Moslem and Duleba [66]).

Figure 3 shows the graphical representation of the membership function used in this paper for the interpretation of the fuzzy linguistic terms as proposed by Kannan et al. [65].

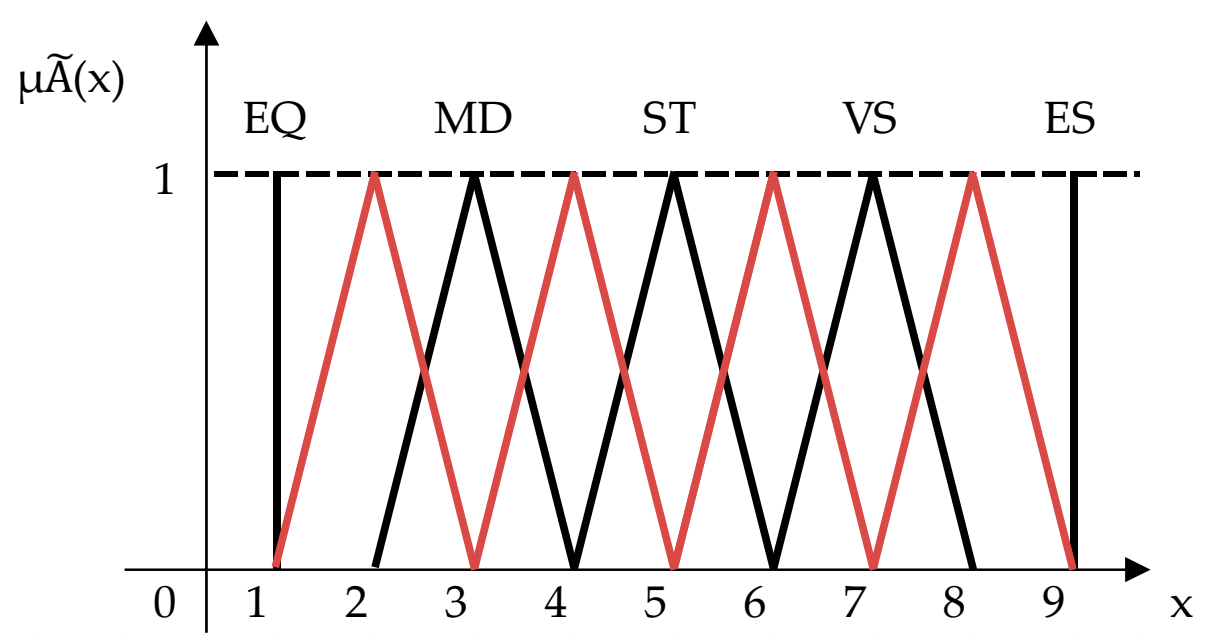

Figure 3. Interpretation of fuzzy linguistic terms (Kannan et al. [65]). 


\subsubsection{The Triangular FAHP Method}

In this paper, the FAHP method is applied for the investigation of the natural hazard risk factors and sub-factors. The FAHP method has been structured and developed according to the following steps:

Step-1: Formulation of a team of experts consisted of two (2) experts from a surface mine operating in northern Greece and one (1) expert from an engineering company involved with projects of the energy sector. The experts filled up a questionnaire properly structured for making a linguistic evaluation of the probability, as risk factor and sub-factor, that each hazard will occur;

Step-2: Setting up the goal, the hierarchy, and identity of each risk factor and sub-factor; Step-3: Construction of the pair-wise comparison matrix, [ak], the elements of which aijk represent the kth experts' preference of the risk factor $i$ over the risk factor $j ; i, j \in N$. The fundamental relationship between the elements of the reciprocal matrix is $\left(a_{i j}\right)$. (aji) $=1$;

Step-4: Production of the average pair-wise comparison matrix, [a] with elements the average values of experts' preferences by applying Equation (10):

$$
\mathrm{A}_{\mathrm{ij}}=\frac{\sum\left(\mathrm{a}_{\mathrm{ij}}{ }^{1}+\mathrm{a}_{\mathrm{ij}}{ }^{2}+\ldots \ldots+\mathrm{a}_{\mathrm{ij}}^{\mathrm{k}}\right)}{\mathrm{k}}(\mathrm{k}: \text { number of experts engaged })
$$

Step-5: Construction of the fuzzy pairwise comparison matrix [] [ã] with elements the fuzzy values, ãij using the linguistic scale of membership function and the operations of TFNs numerical conversion (Table 2).

Step-6: Calculation of the fuzzy geometric mean value of each risk factor $\widetilde{R} i$, according to Buckley's approach (Equation (11)):

$$
\widetilde{\mathrm{R}}_{\mathrm{i}}=\left\{\prod_{\mathrm{j}=1}^{\mathrm{n}} \tilde{\mathrm{A}}_{\mathrm{ij}}\right\}^{1 / \mathrm{n}}=\left(\tilde{\mathrm{A}}_{\mathrm{i} 1} \otimes \tilde{\mathrm{A}}_{\mathrm{i} 2} \otimes \tilde{\mathrm{A}}_{\mathrm{i} 3} \otimes \ldots \tilde{\mathrm{A}}_{\mathrm{in}}\right)^{1 / \mathrm{n}}
$$

Upon determination of geometric means, the vector of fuzzy geometric risk factors is formulated (Equation (12)):

$$
\widetilde{\mathrm{R}}=\left[\widetilde{\mathrm{R}}_{1}, \widetilde{\mathrm{R}}_{2}, \widetilde{\mathrm{R}}_{3}, \ldots, \widetilde{\mathrm{R}}_{\mathrm{n}}\right]^{\mathrm{T}}
$$

Step-7: Definition of the fuzzy risk factors (i.e., the fuzzy relative weights) $\widetilde{W} i$, as follows (Equation (13)):

$$
\widetilde{\mathrm{W}}_{\mathrm{i}}=\widetilde{\mathrm{R}}_{\mathbf{i}} \oplus\left(\widetilde{\mathrm{R}}_{1} \oplus \widetilde{\mathrm{R}}_{2} \oplus \widetilde{\mathrm{R}}_{3} \oplus \ldots \oplus \widetilde{\mathrm{R}}_{\mathrm{n}}\right)^{-1}
$$

Step-8: De-fuzzification of the fuzzy relative weights $\widetilde{W} i$, to determine the crisp values $\mathrm{Wi}$, using the Centre of the Area (CoA) method by applying Equation (14) [72]:

$$
\mathrm{W}_{\mathrm{i}}=\frac{\left(\mathrm{L} \cdot \widetilde{\mathrm{W}}_{\mathrm{i}}+\mathrm{M} \cdot \widetilde{\mathrm{W}}_{\mathrm{i}}+\mathrm{U} \cdot \widetilde{\mathrm{W}}_{\mathrm{i}}\right)}{3}
$$

Step-9: Normalisation of the De-fuzzified relative weights $\widetilde{W} i$ by applying Equation (15):

$$
\mathrm{W}_{\mathrm{Ni}}=\frac{\mathrm{W}_{\mathrm{i}}}{\sum_{\mathrm{i}=1}^{\mathrm{n}} \mathrm{W}_{\mathrm{i}}}, \Sigma \mathrm{W}_{\mathrm{i}}=1 \wedge \mathrm{W}_{\mathrm{i}}>0 ;
$$

Step-10: Determination of the Consistency Index (CI) value of the FAHP using Equation (16):

$$
C I=\frac{\left(\lambda_{\max }-n\right)}{(n-1)}
$$

where $\lambda_{\max }$ is the largest eigenvalue of the pair-wise comparison matrix. 
Step-11: determination of the Consistency Ratio (CR) using Equation (17):

$$
\mathrm{CR}=\frac{\mathrm{CI}}{\mathrm{RI}(\mathrm{n})}
$$

where RI(n) is a Random Index shown in Table $3[51,73]$ that depends on the number of risk factors, $\mathrm{n}$. If $\mathrm{CR}<0.1$, the pair-wise comparison matrix is mathematically consistent and acceptable [51], and the calculated risk factors can be used to analyse disastrous scenarios. Otherwise, a new loop for the questionnaire review by experts is required until the mathematical consistency has been achieved.

Table 2. TFNs analytical conversion operations (Kannan et al. [65]).

\begin{tabular}{ccccc}
\hline Saaty Scale & Definition (Linguistic Terms) & TFNs Values & Reverse Values & TFNs Conversion \\
\hline 1 & Equal (EQ) & $(1,1,1)$ & $1 / 1$ & $(1 / 1,1 / 1,1 / 1)$ \\
3 & Moderate (MD) & $(2,3,4)$ & $1 / 3$ & $(1 / 4,1 / 3,1 / 2)$ \\
5 & Strong (ST) & $(4,5,6)$ & $1 / 5$ & $(1 / 6,1 / 5,1 / 4)$ \\
7 & Very Strong (VS) & $(6,7,8)$ & $1 / 7$ & $(1 / 8,1 / 7,1 / 6)$ \\
9 & Extremely Strong (ES) & $(9,9,9)$ & $1 / 9$ & $(1 / 9,1 / 9,1 / 9)$ \\
2 & & $(1,2,3)$ & $1 / 2$ & $(1 / 3,1 / 2,1 / 1)$ \\
4 & & $(3,4,5)$ & $1 / 4$ & $(1 / 5,1 / 4,1 / 3)$ \\
6 & Intermediate Values & $(5,6,7)$ & $1 / 6$ & $(1 / 7,1 / 6,1 / 5)$ \\
8 & & $(7,8,9)$ & $1 / 8$ & $(1 / 9,1 / 8,1 / 7)$ \\
\hline
\end{tabular}

Table 3. Random Index values (Do et al. [68]).

\begin{tabular}{cccccccccc}
\hline $\mathbf{n}$ & $\mathbf{3}$ & $\mathbf{4}$ & $\mathbf{5}$ & $\mathbf{6}$ & $\mathbf{7}$ & $\mathbf{8}$ & $\mathbf{9}$ & $\mathbf{1 0}$ & $\mathbf{1 1}$ \\
\hline $\mathrm{RI}(\mathrm{n})$ & 0.58 & 0.90 & 1.12 & 1.24 & 1.32 & 1.41 & 1.45 & 1.49 & 1.51 \\
\hline
\end{tabular}

\subsubsection{Risk Breakdown Structure}

The first step of the pre-disaster analysis is the identification of risk factors by investigating the mine operation system concerning the geological, seismic, environmental, and hydrological features and the epidemic records of the mine. Based on these analyses, a risk breakdown structure (RBS) is performed $[74,75]$ reflecting: (a) a taxonomy of the categories of primary risk factors and (b) a partonomy consisted of the groups of risk sub-factors representing further analysis of each main risk.

The identification and breakdown of risk factors are shown in the first two columns of Table 4 based on the detailed work of Spanidis et al. [12] and Pavloudakis et al. [14]. Therefore, more elaboration on RBS stands out of the scope of this paper.

Table 4. Risk Breakdown Structure (RBS) and Probabilities of Occurrence (Pavloudakis et al. [14]).

\begin{tabular}{|c|c|c|c|}
\hline \multirow[t]{2}{*}{ Risk ID } & \multirow[t]{2}{*}{ Risk Factors \& Sub-Factors } & \multicolumn{2}{|c|}{ Probability of Occurrence } \\
\hline & & Factors $\mathbf{P ( i )}$ & Sub-Factors $P(i, j)$ \\
\hline R-1.00 & ATMOSPHERIC (ATM) & \multicolumn{2}{|c|}{$\mathrm{P}(1.00)=0.393$} \\
\hline R-1.01 & Lightning & & $\mathrm{P}(1.01)=0.039$ \\
\hline R-1.02 & Windstorms & & $\mathrm{P}(1.02)=0.043$ \\
\hline R-1.03 & Winter Storms & & $\mathrm{P}(1.03)=0.047$ \\
\hline R-1.04 & Snow Avalanches & & $\mathrm{P}(1.04)=0.013$ \\
\hline R-1.05 & Extreme Rainfalls & & $\mathrm{P}(1.05)=0.141$ \\
\hline R-1.06 & Extreme Frost & & $\mathrm{P}(1.06)=0.004$ \\
\hline R-1.07 & Extreme Snowfalls & & $\mathrm{P}(1.07)=0.004$ \\
\hline R-1.08 & Hailstorms & & $\mathrm{P}(1.08)=0.004$ \\
\hline
\end{tabular}


Table 4. Cont.

\begin{tabular}{|c|c|c|c|}
\hline \multirow[t]{2}{*}{ Risk ID } & \multirow[t]{2}{*}{ Risk Factors \& Sub-Factors } & \multicolumn{2}{|c|}{ Probability of Occurrence } \\
\hline & & Factors $\mathbf{P ( i )}$ & Sub-Factors $P(i, j)$ \\
\hline R-1.09 & Tornados & & $\mathrm{P}(1.09)=0.000$ \\
\hline $\mathrm{R}-1.10$ & Cyclones & & $\mathrm{P}(1.10)=0.000$ \\
\hline R-1.11 & Extreme Summers & & $\mathrm{P}(1.11)=0.098$ \\
\hline $\mathrm{R}-2.00$ & GEOLOGICAL (GEO) & $\mathrm{P}(2$ & 0.183 \\
\hline R-2.01 & Earthquakes & & $\mathrm{P}(2.01)=0.002$ \\
\hline R-2.02 & Soil \& Rock mass movements & & $\mathrm{P}(2.02)=0.037$ \\
\hline R-2.03 & Volcanic eruptions & & $\mathrm{P}(2.03)=0.000$ \\
\hline R-2.04 & Landslides & & $\mathrm{P}(2.04)=0.040$ \\
\hline R-2.05 & Erosion & & $\mathrm{P}(2.05)=0.047$ \\
\hline R-2.06 & Soil Subsidence & & $\mathrm{P}(2.06)=0.057$ \\
\hline R-3.00 & HYDROLOGICAL (HYD) & $\mathrm{P}(3$ & 0.310 \\
\hline R-3.01 & Floods & & $P(3.01)=0.201$ \\
\hline R-3.02 & Droughts & & $\mathrm{P}(3.02)=0.025$ \\
\hline R-3.03 & Mudslides & & $P(3.03)=0.077$ \\
\hline R-3.04 & Extreme sea movements & & $\mathrm{P}(3.04)=0.000$ \\
\hline R-3.05 & Sea erosion & & $P(3.05)=0.006$ \\
\hline $\mathrm{R}-4.00$ & FIRES (FIR) & $\mathrm{P}(4$ & 0.088 \\
\hline R-4.01 & Fires by external sources & & $\mathrm{P}(4.01)=0.018$ \\
\hline R-4.02 & Forest Fires & & $\mathrm{P}(4.02)=0.053$ \\
\hline $\mathrm{R}-4.03$ & Bush Fires & & $\mathrm{P}(4.03)=0.018$ \\
\hline R-5.00 & BIOLOGICAL (BIO) & $\mathrm{P}(5$ & 0.028 \\
\hline R-5.01 & Epidemic crises & & $P(5.01)=0.003$ \\
\hline \multirow[t]{2}{*}{$\mathrm{R}-5.02$} & $\begin{array}{l}\text { Pollution by biological } \\
\text { factors }\end{array}$ & & $P(5.02)=0.025$ \\
\hline & & $\Sigma \mathrm{P}(\mathrm{i})=1.000$ & $\Sigma \mathrm{P}(\mathrm{i} . \mathrm{j})=1.000$ \\
\hline
\end{tabular}

\section{Results}

\subsection{Application of FAHP}

The FAHP method has been applied to determine the probability that the identified risks will occur through a groupware decision-making framework. Initially, separate sessions with a group of experts was arranged to have a better understanding of the fundamental research, the fuzzy analysis concept, the technical procedure of filling-up the questionnaires, and the calculations of the relative weights mentioned in FAHP steps, which reflect the probability of occurrence of the identified risks. Thus, the experts were enabled to make their knowledge on hazardous phenomena explicit, considering the frequency and the effects in the mine operation, and to make the pair-wise comparisons between risk factors and sub-factors as the FAHP requires.

The result of the round of questionnaires filling up was the collection of quantitative data used as inputs in the TFN numbers setting up, the de-fuzzification calculations, and, finally, the structuring of the normalized risk factors vector (or the vector of the crisp values of relative weights reflecting each risk factor/sub-factor) and the consistency control of the FAHP method. Table 5 draws the elements of the initial pair-wise comparison matrix matching with experts' preferences, and Table 6 shows the fuzzified pair-wise comparison matrix. Table 7 presents the fuzzy geometric mean values, the fuzzy weights of risk factors, and the de-fuzzification vector along with the results of consistency control. 
Table 5. Pairwise Comparison Matrix (Based on Saaty [52]).

\begin{tabular}{ccccccc}
\hline Risk ID & Risk Factors & ATM & GEO & HYD & FIR & BIO \\
\hline R-1.00 & ATM & 1.00 & 3.00 & 2.00 & 4.00 & 8.00 \\
R-2.00 & GEO & $1 / 3$ & 1.00 & $1 / 3$ & 4.00 & 8.00 \\
R-3.00 & HYD & $1 / 2$ & 3.00 & 1.00 & 4.00 & 8.00 \\
R-4.00 & FIR & $1 / 4$ & $1 / 4$ & $1 / 4$ & 1.00 & 6.00 \\
R-5.00 & BIO & $1 / 8$ & $1 / 8$ & $1 / 8$ & $1 / 6$ & 1.00 \\
\hline
\end{tabular}

Table 6. Fuzzified pair-wise comparison matrix (based on Buckley [60] and Kannan et al. [65]).

\begin{tabular}{|c|c|c|c|c|c|c|}
\hline Risk ID & Risk Factors & ATM & GEO & HYD & FIR & BIO \\
\hline $\mathrm{R}-1.00$ & ATM & $(1,1,1)$ & $(2,3,4)$ & $(1,2,3)$ & $(3,4,5)$ & $(7,8,9)$ \\
\hline $\mathrm{R}-2.00$ & GEO & $\begin{array}{c}(1 / 4,1 / 3 \\
1 / 2)\end{array}$ & $(1,1,1)$ & $\begin{array}{c}(1 / 4,1 / 3, \\
1 / 2)\end{array}$ & $(3,4,5)$ & $(7,8,9)$ \\
\hline R-3.00 & HYD & $\begin{array}{c}(1 / 3,1 / 2 \\
1 / 1)\end{array}$ & $(2,3,4)$ & $(1,1,1)$ & $(3,4,5)$ & $(7,8,9)$ \\
\hline $\mathrm{R}-4.00$ & FIR & $\begin{array}{c}(1 / 5,1 / 4 \\
1 / 3)\end{array}$ & $\begin{array}{c}(1 / 5,1 / 4 \\
1 / 3)\end{array}$ & $\begin{array}{c}(1 / 5,1 / 4 \\
1 / 3)\end{array}$ & $(1,1,1)$ & $(5,6,7)$ \\
\hline R-5.00 & $\mathrm{BIO}$ & $\begin{array}{c}(1 / 9,1 / 8 \\
1 / 7)\end{array}$ & $\begin{array}{c}(1 / 9,1 / 8 \\
1 / 7)\end{array}$ & $\begin{array}{c}(1 / 9,1 / 8 \\
1 / 7)\end{array}$ & $\begin{array}{c}(1 / 7,1 / 6 \\
1 / 5)\end{array}$ & $(1,1,1)$ \\
\hline
\end{tabular}

Table 7. Fuzzy Analytical Hierarchy Process (FAHP) results and Consistency Control (Based on Saaty [52] and Kannan et al. [65]).

\begin{tabular}{lcccccc}
\hline Risk-ID & Risk Factors & $\begin{array}{c}\text { Fuzzy Geometric } \\
\text { Mean Values }\end{array}$ & Fuzzy Values & $\begin{array}{c}\text { Defuzzified } \\
\text { Values }\end{array}$ & $\begin{array}{c}\text { Normalised } \\
\text { Values }\end{array}$ & $\begin{array}{c}\text { Probability of } \\
\text { Occurrence P(i) }\end{array}$ \\
\hline R-1.00 & ATM & 3.519 & 0.632 & 0.423 & 0.393 & $\mathrm{P}(1.00)=39.3 \%$ \\
R-2.00 & GEO & 1.623 & 0.291 & 0.197 & 0.183 & $\mathrm{P}(2.00)=18.3 \%$ \\
R-3.00 & HYD & 2.825 & 0.507 & 0.333 & 0.310 & $\mathrm{P}(3.00)=31.0 \%$ \\
R-4.00 & FIR & 0.763 & 0.137 & 0.094 & 0.088 & $\mathrm{P}(4.00)=8.8 \%$ \\
R-5.00 & BIO & 0.226 & 0.040 & 0.030 & 0.028 & $\mathrm{P}(5.00)=2.8 \%$ \\
\multicolumn{2}{l}{ Consistency Control: $\mathrm{n}=5 ; \mathrm{CI}=0.102 ; \mathrm{RI}(\mathrm{n})=1.12 ; \mathrm{CR}=\mathrm{CI} / \mathrm{RI}=0.091<0.10$} & 1.000 & $\Sigma \mathrm{P}(\mathrm{i})=100 \%$ \\
\hline
\end{tabular}

The risk sub-factors are the average values of experts' estimation on the proportionality each sub-factor maintains to the probability of the main risk category it belongs, i.e., $\mathrm{P}(1.05)=0.393 \times 35.88 \%=0.141$, where $35.88 \%$ is the average value of experts estimation The complete results or the crisp values of the probability for all risk factors and sub-factors are depicted in the last two columns of Table 4.

\subsection{Risk Assessment}

The risk assessment was performed based on data related to an enormous flood of high intensity that happened a few years ago (Figure 3). After the flood, a detailed field inspection was carried out by mining, environmental, and geotechnical experts across the mining sites and a disaster report was prepared to refer the type and the extent of the various identified damages. The most critical damage includes the following:

- $\quad$ Partial destruction of electrical installations and equipment

- $\quad$ Damage to the roofs of building facilities

- $\quad$ Two (2) weeks stoppage of lignite production caused by the forced shutdown of mining activities

- $\quad$ Destruction of pit surfaces, trenches and slopes (4\% of the mine surface)

- $\quad$ Loss of lignite material (7\% of the mine surface) at descended locations

- $\quad$ Complete destruction of two (2) mining equipment units

- Complete destruction of two (2) belt conveyor lines

A risk assessment was performed, consisting of the: (a) formulation of the risk probability and severity analysis matrix (Table 8). In this matrix, the elements at risk of the mine 
are defined, i.e., people, assets, and environment, as well as the magnitude of the impacts caused by hazardous phenomena and (b) the risk analysis, where the hazardous scenario was interpreted and reflected in quantitative terms, based on the content of risk probability and severity analysis matrix. The risk analysis shown in the elements at risk reflects the field inspection findings. The probability of occurrence of the disastrous events addressed from the FAHP application results. The impacts analysis and the restoration and recovery measures are based on expert judgement (Table 9).

Table 8. Risk Probability and Impacts Severity Matrix (based on Project Management Body of Knowledge [76]).

\begin{tabular}{|c|c|c|c|c|c|c|c|}
\hline \multicolumn{3}{|c|}{ Elements at Risk } & \multicolumn{5}{|c|}{ Probability of Occurrence ${ }^{(1)}$} \\
\hline People & Assets ${ }^{(2)}$ & Environment ${ }^{(3)}$ & $\mathbf{P}(\mathrm{A})$ & $\mathbf{P}(\mathrm{B})$ & $P(C)$ & $P(D)$ & $P(E)$ \\
\hline No injury & No damage, $d=0 €$ & No impact & none & none & none & none & none \\
\hline $\begin{array}{l}\text { First aid } \\
\text { treatment }\end{array}$ & $\mathrm{d} \leq 200 \mathrm{k} €$ & Negligible area $\leq 2 \%$ & $\mathrm{~L}$ & $\mathrm{~L}$ & $\mathrm{~L}$ & $\mathrm{~L}$ & $\mathrm{~L}$ \\
\hline $\begin{array}{l}\text { Lost workday } \\
\text { injury } \leq 3 \text { days }\end{array}$ & $200 \mathrm{k} €<\mathrm{d} \leq 2 \mathrm{M} €$ & Minor $2 \%<$ area $\leq 5 \%$ & $\mathrm{~L}$ & $\mathrm{~L}$ & $\mathrm{~L}$ & M & M \\
\hline $\begin{array}{l}\text { Lost workday } \\
\text { Injury > } 3 \text { days }\end{array}$ & $2 \mathrm{M} €<\mathrm{d} \leq 20 \mathrm{M} €$ & Severe $5 \%<$ area $\leq 10 \%$ & $\mathrm{~L}$ & $\mathrm{~L}$ & M & M & $\mathrm{H}$ \\
\hline $\begin{array}{l}\text { Permanent } \\
\text { disability }\end{array}$ & $20 \mathrm{M} €<\mathrm{d} \leq 200 \mathrm{M} €$ & Major $10 \%<$ area $\leq 20 \%$ & M & M & M & $\mathrm{H}$ & $\mathrm{H}$ \\
\hline Fatality & $\mathrm{d}>200 \mathrm{M} €$ & Catastrophic area $>20 \%$ & M & M & $\mathrm{H}$ & $\mathrm{H}$ & $\mathrm{H}$ \\
\hline \multicolumn{8}{|c|}{ (1) Classification of the Probability of Occurrence: } \\
\hline $\mathrm{P}(\mathrm{A})$-Remote & $0<\mathrm{P}<0.05$ & \multicolumn{6}{|c|}{ Never occurred in the mining industry } \\
\hline P(B)-Unlikely & $0.05<\mathrm{P}<0.10$ & \multicolumn{6}{|c|}{ Has occurred in the mining industry } \\
\hline $\mathrm{P}(\mathrm{C})$-Occasional & $0.10<\mathrm{P}<0.20$ & \multicolumn{6}{|c|}{ Occurred at the mine the last 25 years } \\
\hline P(D)-Probable & $0.20<\mathrm{P}<0.50$ & \multicolumn{6}{|c|}{ Occurred at the mine once per year } \\
\hline $\mathrm{P}(\mathrm{E})$-Frequent & $0.50<\mathrm{P}$ & \multicolumn{6}{|c|}{ Occurred at the mine more than once per year } \\
\hline
\end{tabular}

Severity of Impacts: L = Low (green); M = Medium (yellow); H = High (red); (2) Monetary units: $1 \mathrm{k} €=1000 € ; 1 \mathrm{M} €=1,000,000 € ;$ The cost intervals provided by the mining experts, (3) Environmental impacts: the portion (\%) of mine's area (in $\mathrm{km}^{2}$ ) affected by a hazardous phenomenon.

Table 9. Risk Analysis (1).

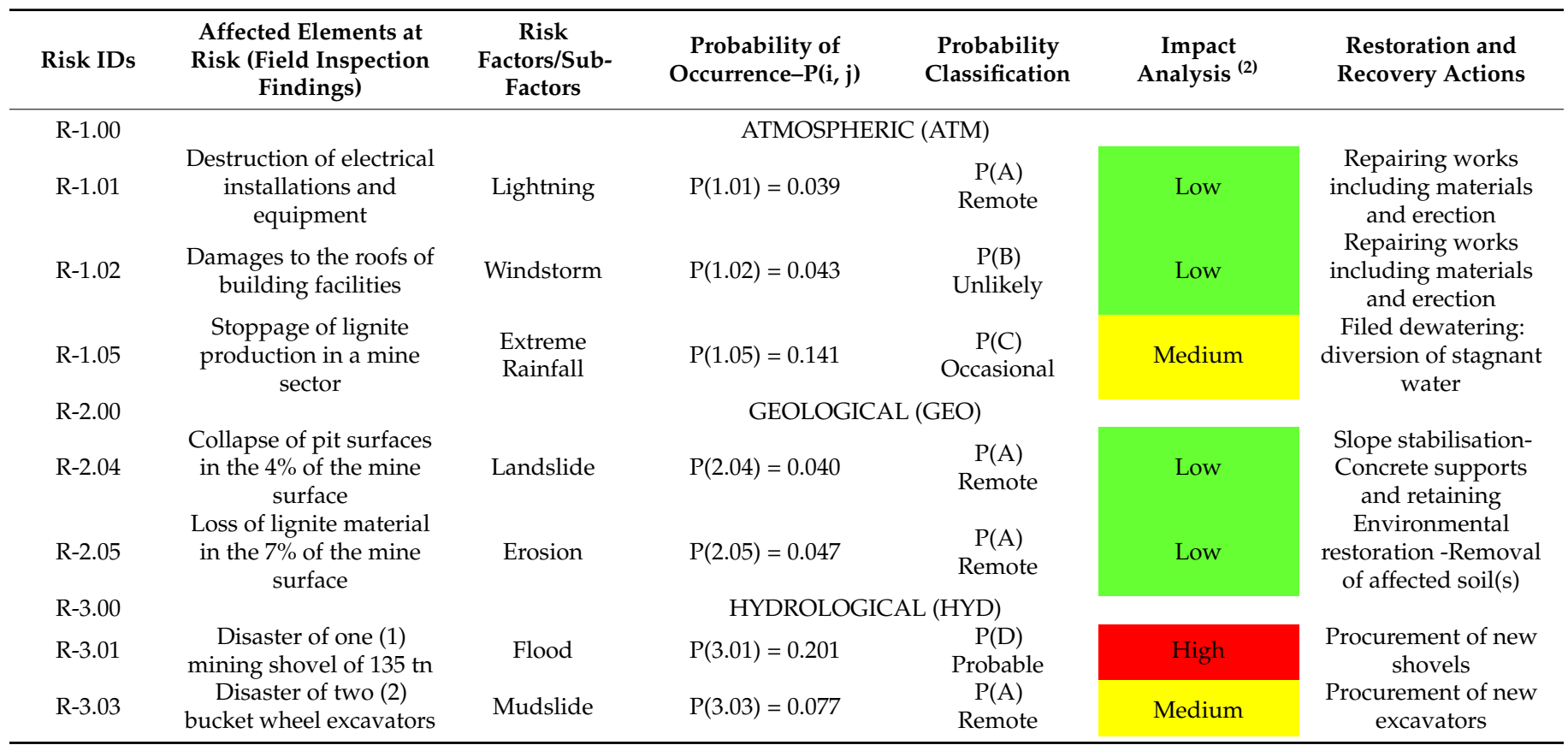

(1) This table presents the complete risk analysis for each "Element at Risk" of the disastrous scenario examined in the case study. (2) The worst impact case is considered. 
It is essential to underline that the risk factors calculated in the FAHP with possible effects to the mining system do not express the frequency of appearance of every specific hazard in nature but reflect the proportional value (in terms of \%) of their occurrence. For example, an earthquake event has a $0.1 \%$ probability of appearance, while the probability of the same event to occur as a unique geophysical phenomenon might be, e.g., $1 \times 10^{-4}$ per year (repletion period) according to the historical seismic records.

\subsection{Pre-Disaster Analysis}

The pre-disaster analysis is critical for the preparation planning and execution of a properly documented, efficient, and cost-effective disaster management project. The result of this analysis is important for mining executives. It constitutes a substantial basis for understanding the various scenarios dealing with phenomena (floods, storms, earthquakes, etc.) with harmful effects in mines and hence to make reasonable decisions for taking the appropriate recovery measures and actions. For this reason, the Expected Value (EV), known in the literature of statistics as "mathematical expectation," has been advised by authors as a linear function appropriate for expressing the cost and time overruns on various scenarios induced by natural hazards in a mining environment $[42,57,77]$. In the case study, the EV was expressed as (Equations (18) and (19)):

$$
\text { Cost overrun: } \operatorname{EV}(C)=\sum \operatorname{EVC}_{(i, j)} \cdot P_{(i, j)}, i=1, \ldots, n ; j=1, \ldots, m
$$

Time overrun: $\operatorname{EV}(T)=\sum \operatorname{EVT}_{(i, j)} \cdot P_{(i, j)}, i=1, \ldots, n ; j=1, \ldots, m, n, m \in N$

where $I$ is the index of the risk factor, $j$ is the index of risk sub-factor under concern, and $P(i, j)$ is the probability of occurrence as an input taken from the RBS shown in Table 4 .

The parameters $\operatorname{EVC}(i, j)$ and $\operatorname{EVT}(i, j)$ express the partial cost and partial time overruns corresponding to impacts caused by a specific risk factor/sub-factor $R(i, j)$. The EVC(i,j) is the Mean Cost, $\mathrm{C}_{\mathrm{M}}$, which is the average of a 500 random values sample produced by a Monte Carlo simulation between a lower and an upper-cost value, $C_{\min }$ and $C_{\max }$, collected from the operation and maintenance records of the mine $\left(C_{\min }<C_{M}<C_{\max }\right)$. Respectively, EVT $(\mathrm{i}, \mathrm{j})$ is the Expected Recovery time consisted of the material/equipment supply time and the time required for the recovery activities into the mine area, such as site and landform restoration, repairing or substituting of machinery and damaged infrastructures, etc. Based on mining records, the expected recovery time $T_{M}$ for each risk sub-factor was calculated using the PERT method among one pessimistic value, $T_{P}$, one optimistic, $\mathrm{T}_{\mathrm{O}}$, and, most likely, $\mathrm{T}_{\mathrm{ML}}$. The $\mathrm{T}_{\mathrm{M}}$ values are calculated using the following Equation (20) [78,79]:

$$
\mathrm{TM}=\frac{(\mathrm{TO}+4 . \mathrm{TML}+\mathrm{TP})}{6}
$$

The complete numerical results of the case study are shown in Table 10. 
Table 10. Time and Cost Overruns ${ }^{(1)}$.

\begin{tabular}{|c|c|c|c|c|c|c|c|c|c|c|c|}
\hline \multirow[b]{2}{*}{ Risk IDs } & \multirow[b]{2}{*}{$\begin{array}{c}\text { Risk } \\
\text { Factors/Sub- } \\
\text { Factors }{ }^{(2)} \\
\mathbf{P ( i ) - P ( i , j )} \\
\end{array}$} & \multirow[b]{2}{*}{$\begin{array}{c}\text { Probability of } \\
\text { Occurrence P(i, j) }\end{array}$} & \multicolumn{4}{|c|}{ Restoration Cost $[\mathrm{k} €]-$ (Monte Carlo Simulation) } & \multicolumn{5}{|c|}{ Recovery Time [Weeks]- (PERT Method) } \\
\hline & & & Cmin & Cmax & $\begin{array}{c}\text { Mean Cost } \\
C_{M}{ }^{(3)}\end{array}$ & $\begin{array}{l}\text { Expected (Partial) } \\
\text { Cost Overrun } \\
\text { EVC }(\mathbf{i}, \mathbf{j})\end{array}$ & $\begin{array}{c}\text { Optimistic } \\
\text { Time }\left[\mathrm{T}_{\mathbf{o}}\right]\end{array}$ & $\begin{array}{l}\text { Pessimistic } \\
\text { Time }\left[T_{p}\right]\end{array}$ & $\begin{array}{l}\text { Most Likely } \\
\text { Time }\left[\mathrm{T}_{\mathrm{ML}}\right]\end{array}$ & $\begin{array}{c}\text { Mean Time } \\
{\left[T_{M}\right]^{(4)}}\end{array}$ & $\begin{array}{c}\text { Expected (Partial) } \\
\text { Time Overrun } \\
\text { EVT }(\mathbf{i}, \mathbf{j})\end{array}$ \\
\hline $\mathrm{R}-1.00$ & ATMOSPHERIC & $(0.393)$ & & & & & & & & & \\
\hline $\mathrm{R}-1.01$ & Lightning & 0.039 & 45.00 & 50.00 & 47.58 & 1.87 & 1.50 & 3.50 & 2.50 & 2.50 & 0.10 \\
\hline $\mathrm{R}-1.02$ & Windstorms & 0.043 & 20.00 & 35.00 & 29.57 & 1.28 & 3.00 & 6.00 & 4.50 & 4.50 & 0.19 \\
\hline $\mathrm{R}-1.03$ & $\begin{array}{l}\text { Extreme } \\
\text { Rainfalls }\end{array}$ & 0.141 & 2500 & 2900 & 2761 & 388.18 & 16.00 & 21.00 & 19.00 & 18.83 & 2.65 \\
\hline $\mathrm{R}-2.00$ & GEOLOGICAL & $(0.183)$ & & & & & & & & & \\
\hline $\mathrm{R}-2.04$ & Landslides & 0.040 & 400 & 600 & 478 & 19 & 16.00 & 24.00 & 20.00 & 20.00 & 0.80 \\
\hline $\mathrm{R}-2.05$ & Erosions & 0.047 & 1000 & 1300 & 1217 & 58 & 28.00 & 40.00 & 35.00 & 34.67 & 1.65 \\
\hline $\mathrm{R}-3.00$ & HYDROLOGICAL & $(0.310)$ & & & & & & & & & \\
\hline R-3.01 & Floods & 0.201 & 4000 & 5000 & 4469 & 900 & 20.00 & 30.00 & 27.00 & 26.33 & 5.30 \\
\hline R-3.02 & Mudslides & 0.077 & 3000 & 4000 & 3744 & 290 & 31.00 & 50.00 & 43.00 & 42.17 & 3.26 \\
\hline \multirow{2}{*}{\multicolumn{2}{|c|}{$\begin{array}{l}\text { Cost Overrun: } \\
\text { Time Overrun: }\end{array}$}} & $\mathrm{EV}(\mathrm{C})=$ & 1658.33 & mil $[€]$ & & & & & & & \\
\hline & & $\mathrm{EV}(\mathrm{T})=$ & 13.95 & weeks ${ }^{(5)}$ & & & & & & & \\
\hline
\end{tabular}

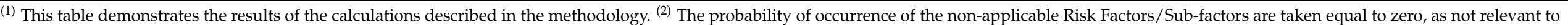

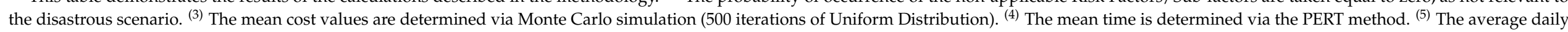
cost of idle time in the mine is provided by experts as approximate to $250-400 \mathrm{k} €$. 


\section{Discussion}

From the previous work, several observations and interesting viewpoints might be drawn:

(a) FAHP is a group decision-making method widely used in mining research as a stand-alone method or combined with other methods [38,58]. FAHP, being more sophisticated and requiring calculations of higher complexity to those of simple AHP, enables the transformation of decision-making problems into objective evaluations. The experts participating in these evaluations use linguistic expressions to explicitly convey their knowledge, which in turn becomes transformable into numerical form via the mathematical rules and operations of fuzzy logic theory. The use of questionnaires ensures confidentiality, objectivity, and quick collection of primary data and validation of the produced results. If so required, several rounds of questionnaire delivery can be arranged for improvement of performance and consistency. The FAHP results can be communicated in simplified forms of presentation, allowing mining executives and operations managers an easy understanding of the problem of natural hazards and the consequences these hazards are entailing for sustainable mining planning. On the other hand, FAHP has its weaknesses, such as computational complexity, mostly when the model of trapezoid membership function has chosen, misalignments of experts' opinions in the pair-wise comparisons, and lowering of the whole performance insofar as the number of the criteria (in our case study: risk factors and sub-factors) under evaluation are getting increased. Notwithstanding the popularity, flexibility, practicality, and low development cost of FAHP, there are also other appropriate decision-making methods for risks quantification e.g., VIKOR (VIekriterijumsko KOmpromisno Rangiranje), DEMATEL(Decision Making Trial and Evaluation Laboratory), PROMETHEE, etc. or other combined methods like AHP/TOPSIS, FAHP/TOPSIS, AHP/PROMETHEE, which can produce results of similar reliability [12]. It should be noted that the selection of the appropriate MCDM method for the determination of the risk factors/sub-factors depends on the philosophy and technical preferences of risk analysts. The FAHP Consistency Ratio $(\mathrm{CR}=0.091)$ is marginally acceptable (i.e., $\left.\Delta=0.1-0.091=9.0 \times 10^{-3}\right)$, although the questionnaires sent twice to experts aiming to achieve the maximum alignment in the definition of values of the initial pre-fuzzy reciprocal matrix. This result might be seen as a gap attributable to perceptional inflexibility, subjectivity, or bias of each expert on how a particular natural hazard is figured out and how frequently it is expected to appear in a complex mining system of long-term exploitation life. For bridging this gap, one approach might be the enlargement of experts group by engaging experts from other scientific disciplines (geologists, meteorologists, etc.) with analogous skills and qualifications so that the average values of the elements in the initial pre-fuzzy reciprocal matrix become as objective as possible. However, the performance of this approach requires previous in-depth research and validation in conditions of real problem-solving assessments with different levels of complexity.

(b) Another remarkable observation is the high score of the cumulative probability of the meteorological and hydrological risks, which equals to $70.24 \%$ (Figure 4). This finding reflects the serious concerns of experts on the effects of climate change that might constitute an emerging and high consequence risk factor as reported in the literature in mine damages of a large scale $[44,45,80]$. Finally, the biological factors, although evaluated as of meagre probability score $(2.75 \%)$, require further investigation with a focus on the widespread impacts in the mining industry, and beyond to the energy economy, as lessons of the COVID-19 pandemic crisis are dictating. 


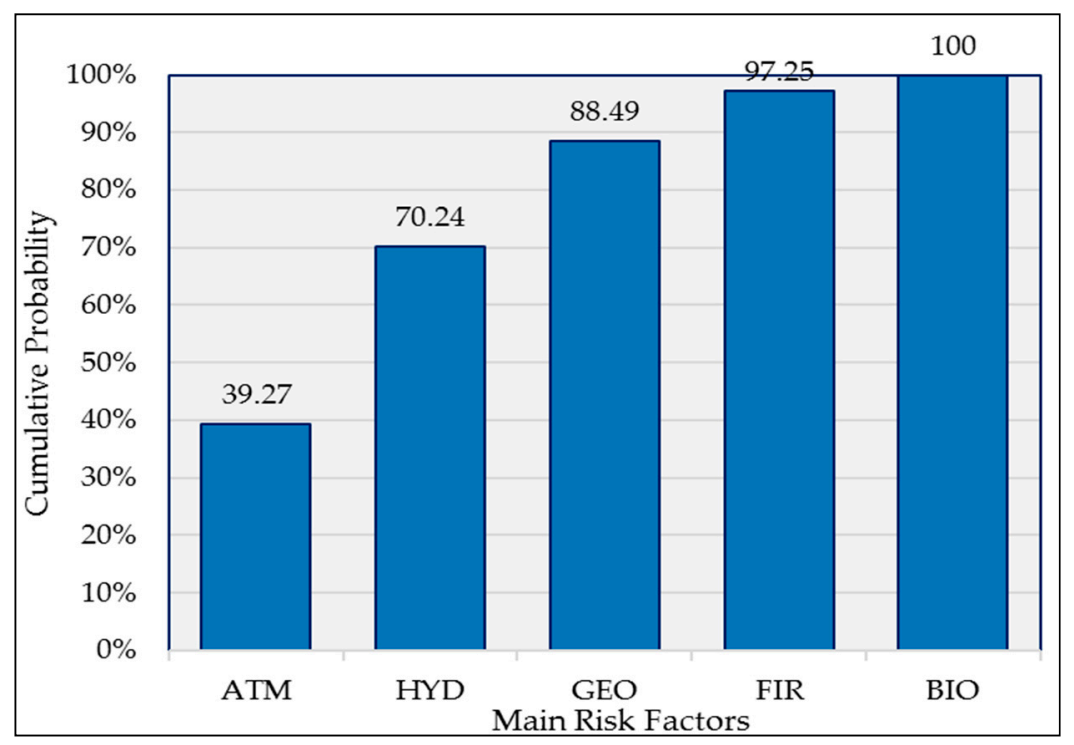

Figure 4. Cumulative Probability of the leading Natural Hazards Risks.

(c) A pre-disaster planning project, to meet its objectives, requires a detailed analysis of all risks that might insert time and cost impacts, as well as safety and health problems for the working personnel in the mine. To this regard, FAHP has been a valuable tool for exploring and collecting expert's knowledge that is particularly useful in quantifying the probability of risks with hazardous effects in mines [38,42,57]. Except for the contribution of FAHP in the determination of risk probabilities, the experts' knowledge and the collection of data (cost and recovery time) from mining archives, contribute to the quantitative analysis of all potential disastrous scenarios and the definition of appropriate proactive and reactive activities and measures to be early taken in a mine [6]. Thus, the scope and capital expenditures (CAPEX) of a predisaster project can be reasonably estimated providing the basis with the mining executives to approve the implementation of such a project, under the condition that all other techno-economic parameters (net present value, internal rate of return, benefit/cost ratio-BCR, etc.) reflect the feasibility of the entire project. The pre-disaster projects must be organised and planned in terms of practicality, efficiency, efficacy, and cost-effectiveness, ensuring fast response in emergency conditions, whenever a disastrous event occurs. The essential functions of an integrated pre-disaster project planning are [30]:

- Project definition (scope, time, budget, resources, limitations, and constraints)

- Project development (planning, organisation, execution, monitoring, feedback, closeout)

- Cost breakdown, budgetary and financial/investment analysis

- Project hazardousness analysis and risk assessment

- Analysis of the mine sustainability in normal and in post-hazard operation conditions

- Pre-disaster preparedness management (functions, mechanisms, infrastructures, equipment, resources)

- Post-disaster initiations and action planning (emergency plans, mitigation, relief, recovery, restoration and repairing actions, solutions for maintaining the mine sustainability, etc.)

- Stakeholder management (mining staff, communities, authorities)

- Health, safety, security, and environmental management (HSSE)

- Project disclosure management

- Training and readiness simulations for mining operators 
To this viewpoint, the suggested methodology might be seen as a low cost and rapid development and performance tool for mining executives and managers constituting an adding value element in frameworks of pre-disaster projects planning. Moreover, it is a tool providing an effective response on issues related to several components of sustainable mining either directly, such as risk management, health and safety performance and prevention of environmental damages, or indirectly, such as responsible design and respect to the right of local communities.

(d) The development of risk-based natural hazards analysis in mines has considerable techno-economic views. It is a matter of fact that risk analysis is an indispensable tool of project management and critical for the cost and extent of proactive/preventive measures to be taken in terms of efficient pre-disaster project development. Practice, however, dictates that indirect costs, $\mathrm{C}_{\mathrm{I}}$, required for the development of risk and quality management (knowledge, resources, quality control, etc.) of a pre-disaster planning project, must be reasonable to enable the balance with the direct costs, $C_{D}$, related to expenses for the prevention and readiness measures (availability of means and equipment, personnel training, mechanisms). In this way, the total cost of predisaster management that corresponds to an efficient level of quality and performance, $\mathrm{C}_{\mathrm{T}}$, will obtain a minimum value, as explained by the following Equation (21):

$$
\mathrm{C}_{\mathrm{T}}=\mathrm{C}_{\mathrm{I}}+\mathrm{C}_{\mathrm{D}}
$$

Figure 5 depicts the trade-off curves of the parameters $C_{I}, C_{D}$, and $C_{T}$ and the optimum cost balancing area aimed by mining project managers for the deployment of a cost-effective pre-disaster project management context.

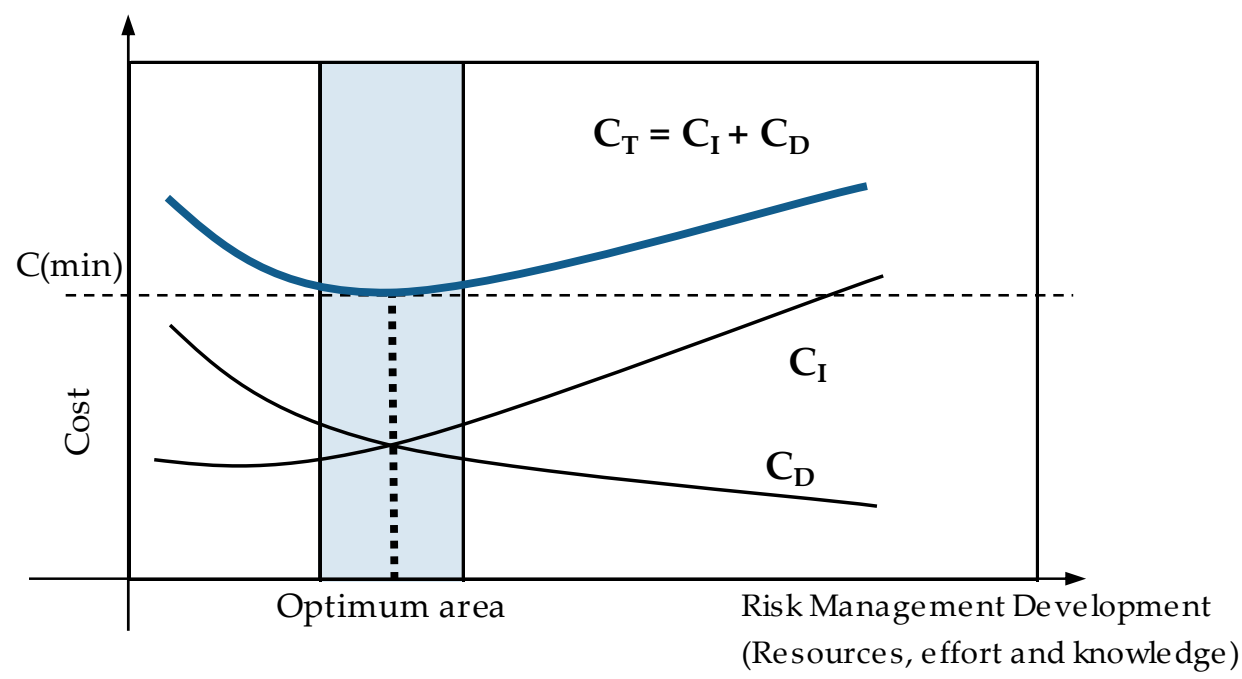

Figure 5. Cost trade-off curves (based on Teli et al. [81]).

The analysis of natural hazards risks on this basis is also a contribution to sustainable mine planning insofar as such financial results are essential for economic growth and they are always threatened by natural hazards.

\section{Conclusions and Perspectives for Further Research}

This paper proposes the application of FAHP in the determination of the probability of occurrence of various risk factors and sub-factors caused by natural hazards with effect to surface mines and the use of these probabilities in performing pre-disaster analyses of time and cost overruns on hazardous scenarios along with recommendations for recovery actions and mitigation measures.

FAHP is suggested as appropriate for aggregation of mining experts' knowledge using linguistic expressions and their quick transformation in quantifiable/numerical form (i.e., crisp values) via an objective and mathematically consistent fuzzification-defuzzification 
process. The outlined results of the FAHP method, as the primary outcome of the case study, constitute a substantial basis for the performing of risk-based estimations on scenarios involving various types of risks caused by hazardous phenomena that should take place in a mine. The combination of FAHP results with Monte Carlo and PERT methods in the analysis of hazardous scenarios allows mining executives to make reasonable decisions for the budget and implementation of mechanisms that ensure quick recovery of a mining system after a natural hazard has occurred.

The methodology advised in this work is a low cost and easily applied tool that considers the sustainability of mining projects, since it demonstrates how the risk management philosophy and techniques can be adapted in the planning of pre-disaster management activities. The early screening of many possible disastrous scenarios contributes to the organization and planning of a project management context including functions and means adequate for tackling/minimization on a proactive/preventive basis. The methodology also contributes to the sustainability of the mine operation throughout its entire life span by eliminating the probability of unexpected expenses for mitigating equipment damages, adverse environmental impacts, and social resistance. This is particularly true in cases of new projects developed in areas with a lack of mining history and in deposits with marginal feasibility due to low ore grade, high stripping ratio, or other reasons.

The conclusions of this study and the contribution of the suggested methodology in the scientific research can be summarized in the following: (i) FAHP represents an objective transformation of experts' multidisciplinary knowledge and expertise into a quantified form that enables probabilistic analysis of various pre-disaster scenarios. Thus, FAHP might be properly modified and transferred in other types of mining operations research, including underground mining; (ii) the numerical results of FAHP dictate that the technical sensitivity of the method might be further improved with an aim a lower consistency ratio to be achieved; (iii) the whole methodology should be integrated by introducing quantifiable socio-economic and sustainability parameters/factors that might be affected when a natural disaster phenomenon has occurred in a surface mining project. Furthermore, some perspectives for further research include: (i) the involvement in the FAHP of an enlarged group of experts, so that, the influence in the values of probabilities and the consistency of the method will be investigated; (ii) the comparative investigation of different MCDM methods (or combination of them) like simple AHP, VIKOR [82], PROMETHEE [83], ELECTREE [84], which can be applied in a similar case study in a way that allows analysis and comparison of the quantitative results and their sensitivity in the decision making contexts of pre-disaster projects; (iii) the investigation of economic parameters (i.e., net present value, internal rate of return, or others) of a pre-disaster project under uncertain conditions that natural hazards could insert in a mining system, based on a sensitivity analysis of the economic parameters of a surface mine in operation with a vulnerability on natural hazards.

Author Contributions: Conceptualization, P.-M.S., C.R., and F.P.; methodology, P.-M.S., C.R., and F.P.; validation, P.-M.S., C.R., and F.P.; formal analysis, P.-M.S., C.R., and F.P.; data curation, P.-M.S., C.R., and F.P.; writing-original draft preparation, P.-M.S., C.R., and F.P.; writing-review and editing, P.-M.S., C.R., and F.P.; visualization, P.-M.S., C.R., and F.P.; supervision, P.-M.S., C.R., and F.P.; project administration, P.-M.S., C.R., and F.P. All authors have read and agreed to the published version of the manuscript.

Funding: This research received no external funding.

Institutional Review Board Statement: Not applicable.

Informed Consent Statement: Not applicable.

Data Availability Statement: The data presented in this study are available on request from the corresponding author.

Conflicts of Interest: The authors declare no conflict of interest. 


\section{References}

1. Knabe, W. Methods and Results of Strip-Mine Reclamation in Germany. Ohio J. Sci. 1964, 64, 74-105.

2. Chuman, T. Restoration Practices used on Post mining Sites and Industrial Deposits in the Czech Republic with an Example of Natural Restoration of Granodiorite Quarries and Spoil Heaps. J. Landsc. Ecol. 2015, 8, 29-46. [CrossRef]

3. Kavvadas, M.; Roumpos, C.; Schilizzi, P. Investigation of the Stability of Deep Excavation Slopes in Continuous Surface Lignite Mines. In Proceedings of the 14th International Symposium of Continuous Surface Mining (ISCSM), Thessaloniki, Greece, 23-26 September 2018; pp. 377-393.

4. UN-ISDR. Terminology of Disaster Risk reduction. United Nations; International Strategy for Disaster Reduction: Geneva, Switzerland, 2004.

5. ADPC. Building Disaster Risk Reduction in Asia: A Way Forward ADPC Looks Ahead to 2015; Asian Disaster Preparedness Center: Bangkok, Thailand, 2004.

6. Moe, T.L.; Pathranarakul, P. An integrated approach to natural disaster management. Disaster Prev. Manag. 2006, 15, 396-413. [CrossRef]

7. Van Westen, C.J. Remote Sensing and GIS for Natural Hazards Assessment and Disaster Management; Schroder, J.F., Bishop, M.P., Eds.; Academic Press: San Diego, CA, USA, 2013.

8. Hewitt, K. , Burton, I. The Hazardousness of a Place: A Regional Ecology of Damage Events; University of Toronto Press: Toronto, ON, Canada, 1971. [CrossRef]

9. Dey, B.; Singh, R.B. Natural Hazards and Disaster Management. Central Board of Secondary Education (CBSE), 1st ed.; Central Board of Secondary Education: Delhi, India, 2006.

10. Nelson, S. Natural Disasters \& Assessing Hazards and Risk, Course Handout for Earth and Environmental Sciences 3050: Natural Disasters; Tulane University, Earth and Environmental Sciences Department: New Orleans, LA, USA, 2014.

11. Roumpos, C.; Spanidis, P.-M. A project management approach to open - pit lignite mine planning and exploitation [open-pit project management]. World Coal 2003, 55-61.

12. Spanidis, P.M.; Roumpos, C.; Pavloudakis, F. A Multi-Criteria Methodology for Low-Risk Evaluation of Mine Closure Restoration in Continuous Surface Lignite Mining Projects. In Proceedings of the 14th International Symposium of Continuous Surface Mining (ISCSM), Thessaloniki, Greece, 23-26 September 2018; pp. 563-578.

13. Roumpos, C.; Spanidis, P.-M.; Pavloudakis, F. Land reclamation planning of continuous surface lignite mines in closure phase: A risk-based investigation. In Proceedings of the 14th International Symposium of Continuous Surface Mining (ISCSM), Thessaloniki, Greece, 23-26 September 2018; pp. 551-562.

14. Pavloudakis, F.; Spanidis, P.-M.; Roumpos, C. Investigation of Natural and Technological Hazards and associated Risks in Surface Lignite Mines. In Proceedings of the 2nd International Conference on Natural Hazards \& Infrastructure (ICONHIC), Chania, Crete, Greece, 23-26 June 2019.

15. EM-DAT. The OFDA/CRED International Disaster Database; Universite Catholique de Louvain: Brussels, Belgium, 2009.

16. Tischew, S.; Krimer, A.; Lorenz, A. Alternative Restoration Strategies in Former Lignite Mining Areas of Eastern Germany, Biodiversity: Structure and Function; EOLSS Publishers Co Ltd.: Oxford, UK, 2009.

17. Kasztelewicz, Z. Approaches to post-mining land reclamation in Polish Opencast lignite mining. Civ. Environ. Eng. Rep. 2014, 12, 55-67. [CrossRef]

18. Iannacchione, A.; Varley, F.; Brady, T. The Application of Major Hazard Risk Assessment (MHRA) to Eliminate Multiple Fatality Occurrences in the US Minerals Industry; Dept. of Health \& Human Services, Centers for Disease Control and Prevention, National Institute for Occupational Safety and Health, Spokane Research Laboratory Spokane: Washington, USA, 2008.

19. Tripathy, D.P.; Ala, C.K. Identification of safety hazards in Indian underground coal mines. J. Sustain. Min. 2018, 17, 175-183. [CrossRef]

20. Abbasi, S. Defining Safety Hazards \& Risks in Mining Industry: A Case-Study in United States. Asian J. Appl. Sci. Technol. (AJAST) 2018, 2, 1071-1078.

21. Domingues, C.R.; Martinez, I.V.; Pena, P.M.P.; Ochoa, A.R. Analysis and evaluation of risks in underground mining using the decision matrix risk-assessment (DMRA) technique, in Guanajuato, Mexico. J. Sustain. Min 2019, 18, 52-59. [CrossRef]

22. Donoghue, A.M. Occupational health hazards in mining: An overview. Occup. Med. 2004, 54, 283-289. [CrossRef]

23. Wang, Y.I.; Yang, W.; Li, M.; Liu, X. Risk assessment of floor water inrush in coal mines based on secondary fuzzy comprehensive evaluation. Int. J. Rock Mech. Min. Sci. 2012, 52, 50-55. [CrossRef]

24. Pavloudakis, F.; Roumpos, C.; Galetakis, M. Public acceptance of surface mining projects and the determination of the marginal environmental cost. Int. J. Min. Reclam. Environ. 2012, 26, 292-308. [CrossRef]

25. Azhari, A.; Ozbay, U. Investigating the effect of earthquakes on open pit mine slopes. Int. J. Rock Mech. Min. Sci. 2017, 100, 218-228. [CrossRef]

26. Park, J.H.; Edraki, M.; Baumgartl, T. A practical testing approach to predict the geochemical hazards of in-pit coal mine tailings and rejects. CATENA 2017, 148, 3-10. [CrossRef]

27. Kasap, Y.; Subaşı, E. Risk assessment of occupational groups working in open pit mining: Analytic Hierarchy Process. J. Sustain. Min. 2017, 16, 38-46. [CrossRef]

28. Ferrari, F.; Giacomini, A.; Thoeni, K.; Lambert, C. Qualitative evolving rockfall hazard assessment for high-walls. Int. J. Rock Mech. Min. Sci. 2017, 98, 98-101. [CrossRef] 
29. McQuillan, A.; Canbulat, I.; Payne, D.; Oh, J. New risk assessment methodology for coal mine excavated slopes. Int. J. Min. Sci. Technol. 2018, 28, 583-592. [CrossRef]

30. Lemly, A.D. Environmental hazard assessment of Benga Mining's proposed Grassy Mountain Coal Project. Environ. Sci. Policy 2019, 96, 105-113. [CrossRef]

31. Dos Santos, T.B.; Lana, M.S.; Pereira, T.C.; Canbulat, I. Quantitative hazard assessment system (Has-Q) for open pit mine slopes. Int. J. Min. Sci. Technol. 2019, 29, 419-427. [CrossRef]

32. PMI. A Guide to Project Management Body of Knowledge (PMBOK), 6th ed.; Project Management Institute, Inc.: Newtown Square, PA, USA, 2019.

33. O'Keefe, P.; Westgate, K.; Wisner, B. Taking the naturalness out of natural disasters. Nature 1976, 260, 566-567. [CrossRef]

34. Baroudi, B.; Rapp, R. A project management approach to disaster response and recovery operations. In Proceedings of the 36th Australasian University Building Educators Association (AUBEA) Conference, Gold Coast, Australia, 27 April 2011 ; pp. 17-28.

35. FEMA. HAZUS-MH. FEMA's Methodology for Estimating Potential Losses from Disasters; US Federal Emergency Management Agency: Hyattsville, USA, 2004.

36. Brundl, M.; Romang, H.E.; Bischof, N.; Rheinberger, C.M. The Risk concept and its application in Natural Hazard Risk Management in Switzerland. Nat. Hazards Earth Syst. Sci. 2009, 9, 801-813. [CrossRef]

37. Yazdani-Chamzini, A.; Yakhchali, S.H. Handling equipment selection in open pit mines based on group decision making. Int. J. Ind. Eng. Comput. 2012, 3, 907-924. [CrossRef]

38. Mahase, M.J.; Musingwini, C.; Nhleko, A.S. A survey of applications of multi-criteria decision analysis methods in mine planning and related case studies. J. South. Afr. Inst. Min. Metall. 2016, 116, 1051-1056. [CrossRef]

39. Vlachos, T. A Review of the effectiveness of Health \& Safety Management Systems according to OHSAS 18001 standard at PPC'S lignite mines. In Proceedings of the 14th International Symposium of Continuous Surface Mining (ISCSM), Thessaloniki, Greece, 23-26 September 2018; pp. 428-436.

40. Wang, S.Q.; Dulaimi, M.F.; Aguria, M.Y. Risk Management framework for Construction Projects in Developing Countries. Constr. Manag. Econ. 2004, 22, 237-252. [CrossRef]

41. Kwak, Y.H.; Anbari, F.T. Analysing Project Management research: Perspectives from Top Management Journals. Int. J. Proj. Manag. 2009, 27, 435-446. [CrossRef]

42. Dey, P.K. Project risk management using multiple criteria decision-making technique and decision tree analysis: A case study of Indian oil refinery. Prod. Plan. Control 2011, 1-19. [CrossRef]

43. Pavloudakis, F.; Galetakis, M.; Roumpos, C. A spatial decision support system for the optimal environmental reclamation of open-pit coal mines in Greece. Int. J. Min. Reclam. Environ. 2009, 23, 291-303. [CrossRef]

44. Ignjatović, D.; Jovančić, P.; Pavlović, V. Estimation of Damage on the Equipment during the Floods in Opencast Mines TamnavaWest Field and Veliki Crljeni. In Proceedings of the 13th International Symposium of Continuous Surface Mining (ISCSM), Belgrade, Serbia, 13-14 September 2016; pp. 137-148.

45. Pavlović, N.; Ignjatović, D.; Pavlović, V. Control of Social and Environmental Risks during Opencast Lignite Mining. In Proceedings of the 14th International Symposium of Continuous Surface Mining (ISCSM), Thessaloniki, Greece, 23-26 September 2018; pp. 413-427.

46. Spanidis, P.-M.; Roumpos, C.; Pavloudakis, F. A Methodology for Natural Hazards Risk Management in continuous Surface Lignite Mines. In Proceedings of the 2nd International Conference on Natural Hazards \& Infrastructure (ICONHIC), Chania, Greece, 23-26 June 2019.

47. Anawar, H.M. Impact of climate change on acid mine drainage generation and contaminant transport in water ecosystems of semi-acid and acid mining areas. Phys. Chem. Earth Parts A/B/C 2013. [CrossRef]

48. Candeias, C.; Ávila, P.; Coelho, P.; Teixeira, J.P. Reference Module in Earth Systems and Environmental Sciences. Mining Activities: Health Impacts; Elsevier: Amsterdam, The Netherlands, 2018.

49. Liu, R.; Cheng, W.; Yua, Y.; Xu, Q. Human factors analysis of major coal mine accidents in China based on the HFACS-CM model and AHP method. Int. J. Ind. Ergon. 2018, 68, 270. [CrossRef]

50. Hassan, T.; Moidu, S.; Riyasa, J.; Kuenzerb, C. Remote sensing of coal fires in India: A review. Earth-Sci. Rev. 2018, 187, 338-355.

51. Saaty, T.L. The Analytic Hierarchy Process; McGraw-Hill International: New York, NY, USA, 1980.

52. Saaty, T.L. Application of the AHP in project management. Int. J. Proj. Manag. 2008, 19, $19-27$.

53. Velasquez, M.; Hester, P.T. An Analysis of Multi-Criteria Decision Making Methods. Int. J. Oper. Res. 2013, 10, 56-66.

54. Oreski, D. Strategy development by using SWOT-AHP. TEM J. 2012, 1, 283-291.

55. Triantaphyllou, E.; Shu, B.; Sanchez-Nieto, S.; Ray, T. Multi-Criteria Decision Making: An Operations Research Approach. In Encyclopedia of Electrical and Electronics Engineering; Webster, J.G., Ed.; John Wiley \& Sons: New York, NY, USA, 1998; Volume 15, pp. 175-186.

56. Gupta, V. Comparative performance of contradictory and non- contradictory judgement matrices in AHP under qualitative and quantitative metrics. Int. J. Decis. Support Syst. Technol. 2018, 10, 21-38. [CrossRef]

57. Dey, P.K. Project Risk Management: A Combined Analytic Hierarchy Process and Decision Tree Approach. Cost Eng. 2002, 44, 13-26.

58. Spanidis, P.-M.; Roumpos, C.; Pavloudakis, F. A Multi-Criteria Approach for the Evaluation of Low Risk Restoration Projects in Continuous Surface Lignite Mines. Energies 2020, 13, 2179. [CrossRef] 
59. Tah, J.; Carr, V. A proposal for Construction Project Risk Assessment using Fuzzy Logic. Constr. Manag. Econ. 2000, 18, 491-500. [CrossRef]

60. Buckley, J.J. Fuzzy hierarchical analysis. Fuzzy Sets Syst. 1985, 17, 233-247. [CrossRef]

61. Chang, D.Y. Applications of the extent analysis method on Fuzzy AHP. Eur. J. Oper. Res. 1996, 95, 649-655. [CrossRef]

62. Chen, C.T. Extensions of the TOPSIS for group decision making under fuzzy environment. Fuzzy Sets Syst. 2000, 114, 1-9. [CrossRef]

63. Esmaeli, A.; Kahnali, R.A.; Rostamzadeh, R.; Zavadskas, E.K.; Sepahvand, A. The Formulation of Organizational Strategies through Integration of Freeman Model SWOT and Fuzzy MCDM Methods: A Case Study of Oil Industry. Transform. Bus. Econ. 2014, 13, 602-627.

64. Chen, Y.-H.; Wang, T.-C.; Wu, C.-Y. Strategic decisions using the fuzzy PROMETHEE for IS outsourcing. Expert Syst. Appl. 2011, 38, 13216-13222. [CrossRef]

65. Kannan, G.; Roohollah, K.; Jafarian, A. A fuzzy multi criteria approach for measuring sustainability performance of a supplier based on triple bottom line approach. J. Clean. Prod. 2013, 47, 345-354. [CrossRef]

66. Moslem, S.; Duleba, S. Sustainable Urban Transport Development by Applying a Fuzzy-AHP Model: A case Study from Mersin, Turkey. Urban Sci. 2019, 3, 55. [CrossRef]

67. Zadeh, L.A. Fuzzy Sets. Information and Control 1965, 8, 338-353. [CrossRef]

68. Do, Q.H.; Chen, J.-F.; Hsieh, H.-N. Trapezoidal Fuzzy AHP and Fuzzy Comprehensive Evaluation Approaches for evaluating Academic Library Service. WSEAS Trans. Comput. 2015, 14, 607-619.

69. Zimmerman, H.J. Fuzzy Set Theory and Its Applications; Kluwer: Boston, MA, USA, 1992.

70. Lima, F.R.; Osiro, L.; Carpinetti, L.C.R. A comparison between Fuzzy AHP and Fuzzy TOPSIS methods to supplier selection. Appl. Soft Comput. 2014, 21, 194-209. [CrossRef]

71. Rouyendegh, B.D.; Erkan, T.E. Selection of Academic staff using the Fuzzy AHP: A pilot study. Tech. Vjesn. 2012, 19, 923-929.

72. Chou, S.-W.; Chang, Y.-C. The implementation factors that influence the ERP (Enterprise Resource Planning) Benefits. Decision Support Systems 2008, 1, 149-157. [CrossRef]

73. Golden, B.; Wasil, E.; Harker, P. (Eds.) The Analytic Hierarchy Process: Applications and Studies; Springer-Verlag: Heidelberg, Germany, 1989.

74. Hillson, D. Use a Risk Breakdown Structure (RBS) to Understand Your Risks. In Proceedings of the Project Management Institute Annual Seminars \& Symposium, San Antonio, TX, USA, 3-10 October 2002.

75. Carter, B.; Hanckok, T.; Morin, J.-M.; Robins, N. Introducing RISKMAN; Blackwell: Oxford, UK, 1994.

76. Project Management Body of Knowledge (PMBOK), 5th ed; Project Management Institute: Newtown Square, PA, USA, 2013.

77. Brink, D. Essential of Statistics; BookBoon: London, UK, 2008.

78. Meredith, J.; Mantel, S., Jr. Project Management-A Managerial Approach, 7th ed.; John Wiley \& Sons, Inc.: Hoboken, NJ, USA, 2009.

79. Taha, H.A. Operations Research. Macmillan Publishing Co., Inc.: Indianapolis, IN, USA, 1987; pp. $468-487$.

80. Phillips, J. Climate change and surface mining: A review of environment-human interactions and their spatial dynamics. Appl. Geogr. 2016, 74, 95-108. [CrossRef]

81. Teli, S.N.; Magali, V.S.; Bushi, U.M. In Proceedings of the Role of Cost of Quality in the Automotive Industry. National Conference on Recent Trends in Mechanical Engineering (NCRTME), Datta Meghe College of Engineering, NaviMumbai, India, 28-29 August 2010.

82. Opricovic, S.; Tzeng, G.-H. The Compromise solution by MCDM methods: A comparative analysis of VIKOR and TOPSIS. Eur. J. Oper. Res. 2004, 156, 445-455. [CrossRef]

83. Brans, J.P.; Vincke, P. A preference ranking organisation method: The PROMETHEE method for MCDM. Manag. Sci. 1985, 31, 647-656. [CrossRef]

84. Bernard, R. Classement et choix en présence de points de vue multiples (la méthode ELECTRE). Rev. d'Informatique Rech. Opérationelle (RIRO) 1968, 8, 57-75. 